\title{
Genetic engineering approaches to improve post-translational modification of biopharmaceuticals in different production platforms
}

Amann, Thomas; Schmieder, Valerie; Kildegaard, Helene Faustrup; Borth, Nicole; Andersen, Mikael Rørdam

\section{Published in:}

Biotechnology and Bioengineering

Link to article, DOI:

10.1002/bit.27101

Publication date:

2019

Document Version

Peer reviewed version

Link back to DTU Orbit

Citation (APA):

Amann, T., Schmieder, V., Kildegaard, H. F., Borth, N., \& Andersen, M. R. (2019). Genetic engineering approaches to improve post-translational modification of biopharmaceuticals in different production platforms. Biotechnology and Bioengineering, 116(10), 2778-2796. https://doi.org/10.1002/bit.27101

\section{General rights}

Copyright and moral rights for the publications made accessible in the public portal are retained by the authors and/or other copyright owners and it is a condition of accessing publications that users recognise and abide by the legal requirements associated with these rights.

- Users may download and print one copy of any publication from the public portal for the purpose of private study or research.

- You may not further distribute the material or use it for any profit-making activity or commercial gain

- You may freely distribute the URL identifying the publication in the public portal 


\section{Are you evaluating a potential manufacturing partner?}

\section{It's important to find one who can} meet your current and future needs.

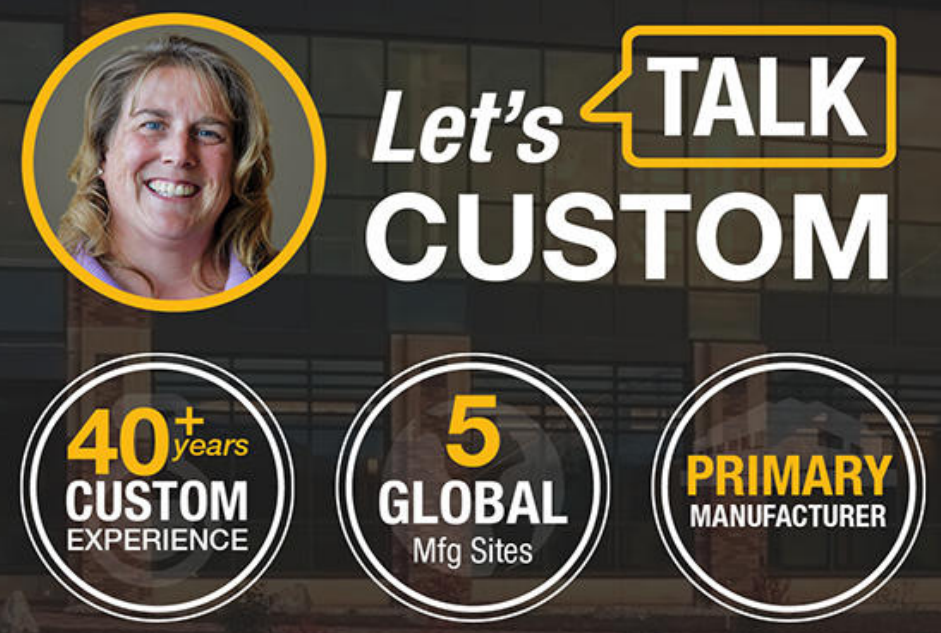

Custom manufacturing often appears daunting, with so many options, standards and possibilities. There's no need to figure it out alone. We will help you find the right solution for your specifications and your timetable.

Learn more with our free webinar: 
Valerie Schmieder ORCID iD: 0000-0002-6104-7342

Nicole Borth ORCID iD: 0000-0001-6324-9338

Mikael Rørdam Andersen ORCID iD: 0000-0003-4794-6808

\section{Genetic engineering approaches to improve post-translational modification of biopharmaceuticals in different production platforms}

Thomas Amann ${ }^{1 \#}$, Valerie Schmieder ${ }^{2,3 \#}$, Helene Faustrup Kildegaard ${ }^{1}$, Nicole Borth ${ }^{3}$, Mikael Rørdam Andersen ${ }^{4 *}$

${ }^{1}$ The Novo Nordisk Foundation Center for Biosustainability, Technical University of Denmark, Kgs. Lyngby, Denmark

${ }^{2}$ acib GmbH, Austrian Centre of Industrial Biotechnology, Graz, Austria

${ }^{3}$ Department of Biotechnology, BOKU University of Natural Resources and Life Sciences, Vienna, Austria

${ }^{4}$ Department of Biotechnology and Biomedicine, Technical University of Denmark, Kgs. Lyngby, Denmark

\# These authors contributed equally to this publication

* Corresponding Author: Mikael Rørdam Andersen

This article has been accepted for publication and undergone full peer review but has not been through the copyediting, typesetting, pagination and proofreading process, which may lead to differences between this version and the Version of Record. Please cite this article as doi: 10.1002/bit.27101.

This article is protected by copyright. All rights reserved. 
Department of Biotechnology and Biomedicine

Technical University of Denmark

2800 Kgs. Lyngby, Denmark

$+4545252675$

mr@bio.dtu.dk

\section{Abbreviations}

$\boldsymbol{\alpha}$, alpha; $\boldsymbol{\beta}$, beta; $\boldsymbol{\gamma}$, gamma; 2-OST, 2-O-Sulfotransferase; A. thaliana, Arabidopsis thaliana; Ab, antibody; ADCC, antibody-dependent cell-mediated cytotoxicity; ALG, NAcetylglucosaminyltransferase; Asn, asparagine; asRNA, antisense RNA; B.mori, Bombyx mori; B3GALT, $\quad \beta-1,3-$-Galactosyltransferase; $\quad$ B3GNT $, \quad \beta-1,3-\mathrm{N}$-acetylglucosaminyltransferase;

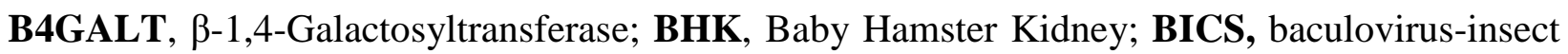
cell system; BY-2, Bright Yellow 2; C1GALT1, Core 1 Synthase Glycoprotein-NAcetylgalactosamine $\quad 3-\beta$-Galactosyltransferase $\quad 1 ; \quad$ C2GNT, Glucosaminyl (N-Acetyl) Transferase, Core 2; C3GNT, Glucosaminyl (N-Acetyl) Transferase, Core 3; C5-epi, C5epimerase; CAP, CEVEC’s Amniocyte Production; Cas, CRISPR-associated; CDC, complement-dependent cytotoxicity; CHO, Chinese Hamster Ovary; CMAH, Cytidine Monophospho-N-Acetylneuraminic Acid Hydroxylase; COSMC, C1GALT1 Specific Chaperone 1; CST, Cerebroside Sulfotransferase; CRISPR, clustered regularly interspaced short palindromic repeats; crRNA, CRISPR RNA; dCas9, dead Cas9; DSB, double-strand break; $\boldsymbol{E}$. coli, Escherichia coli; EMEA, European Medicines Agency; Fc, fragment crystallizable; FCS, Fetal Calf Serum; FDA, US Food and Drug Administration; FLC2, Flavin Carrier Protein 2; 
FDL, fused lobes gene; FUT8, Fucosyltransferase 8; GalNAc, N-Acetylgalactosamine; GALE, UDP-Galactose-4-Epimerase; GALNT2, Polypeptide N-Acetylgalactosaminyltransferase 2; GC, glucocerebrosidase; GGCX, $\gamma$-Glutamyl Carboxylase; GM-CSF, Granulocyte-Macrophage Colony-Stimulating Factor; GNE, Glucosamine (UDP-N-Acetyl)-2-Epimerase; GNT, Nacetylglucosaminyltransferase; GOI, gene of interest; GST-SfManI, $\boldsymbol{\beta}$-Trace, GST-tagged soluble domain of the Sf class I Golgi mannosidase; gRNA, guide RNA; H. Polymorpha, Hansenula polymorpha; HCP, host cell proteins; HDR, homology directed repair; HEK293, Human Embryonic Kidney 293; HeLa, Henrietta Lack’s; HS, Heparan sulfate; HS3ST, Heparan Sulfate Glucosamine 3-O-Sulfotransferase; IFN- $\boldsymbol{\alpha}$, interferon- $\alpha$; IFN- $\boldsymbol{\gamma}$, interferon- $\gamma$; IgA, Immunoglobulin A; IgG, Immunoglobulin G; InDel, insertion/deletion; KD, knockdown; kfo, UDP-Glucose-4-Epimerase; KI, knockin; KO, knockout; L. minor, Lemna minor; mAb, monoclonal antibody; MAN, Mannosidase; Man3GlcNAc2, $\alpha$-D-Mannopyranosyl-(1->3)-[ $\alpha$-Dmannopyranosyl-(1->6)]- $\beta$-D-mannopyranosyl-(1->4)-2-acetamido-2-deoxy- $\beta$-Dglucopyranosyl-(1-\&gt;4)-2-acetamido-2-deoxy- $\beta$-D-glucopyranose; MGAT2, $\alpha$-1,6-MannosylGlycoprotein $\beta-1,2-N$-Acetylglucosaminyltransferase 2; MNN, $\alpha$-1,3-Mannosyltransferase; $N$. benthamiana, Nicotiana benthamiana; N. tabacum, Nicotiana tabacum; ncRNA, non-coding RNA; Neu5Gc, N-glycolylneuraminic acid; NGS, next-generation sequencing; NHEJ, nonhomologous end joining; NT-1, Nicotiana tabacum 1 cell; OCH1, $\alpha-1,6-$ Mannosyltransferase; OE, overexpression; P. pastoris, Pichia pastoris; PAM, protospacer adjacent motif; PDIA2, Protein Disulfide Isomerase Family A Member 2; pglB, Oligosaccharyltransferase pglB; POMGNT1, Protein O-Linked Mannose N-Acetylglucosaminyltransferase 1 ( $\beta-1,2-)$; PSGL1, Selectin P ligand; PTM, post-translational modification; rh, recombinant human; rhC1INH, recombinant human C1 inhibitor; rhEPO, recombinant human erythropoietin; rhF, recombinant

This article is protected by copyright. All rights reserved. 
human coagulation factor; rhG-CSF, recombinant granulocyte colony-stimulating factor; rhGH, recombinant human growth hormone; RNAi, RNA interference; RSV-F, respiratory syncytial virus protein F; S. cerevisiae, Saccharomyces cerevisiae; scFv, single-chain variable fragment; Sf, Spodoptera frugiperda; sgRNA, single guide RNA; shRNA, small hairpin RNA; siRNA, small interfering RNA; SLC35A2, Solute Carrier Family 35 Member A2; SRPK1, Serine/Threonine-Protein Kinase 1; ST6GAL, ST6 $\beta$-Galactoside a-2,6-Sialyltransferase; STT3D, Dolichyl-Diphosphooligosaccharide Protein Glycosyltransferase Subunit STT3; TALEN, transcription activator-like effector nuclease; TNFR2, Tumor Necrosis Factor Receptor 2; tracrRNA, trans-acting RNA; VKORC1, Vitamin K Epoxide Reductase Complex Subunit 1; VLPs, virus-like particles; WBPP,UDP-GlcNAc C4 Epimerase; XYLT, Xylosyltransferase; Y. lipolytica, Yarrowia lipolytica; YFP, yellow fluorescent protein; ZFN, zinc finger nuclease

\begin{abstract}
The number of approved biopharmaceuticals, where product quality attributes remain of major importance, is increasing steadily. Within the available variety of expression hosts, the production of biopharmaceuticals faces diverse limitations with respect to post-translational modifications (PTM), while different biopharmaceuticals demand different forms and specifications of PTMs for proper functionality. With the growing toolbox of genetic engineering technologies, it is now possible to address general as well as host- or biopharmaceutical-specific product quality obstacles.
\end{abstract}

In this review we present diverse expression systems derived from mammalians, bacteria, yeast, plants, and insects as well as available genetic engineering tools. We focus on genes for

This article is protected by copyright. All rights reserved. 
knockout / knockdown and overexpression for meaningful approaches to improve biopharmaceutical PTMs and discuss their applicability as well as future trends in the field.

\section{Graphical Abstract}

The number of approved biopharmaceuticals, where product quality attributes remain of major importance, is increasing steadily. Within the available variety of expression hosts, the production of biopharmaceuticals faces diverse limitations with respect to post-translational modifications (PTM), while different biopharmaceuticals demand different forms and specifications of PTMs for proper functionality.

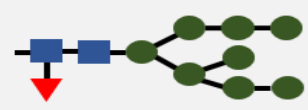

high mannose

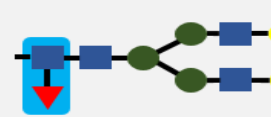

core fucosylation

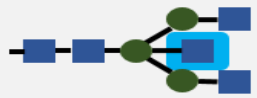

bisecting $\mathrm{N}$-glycan

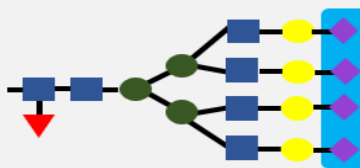

terminal sialylation

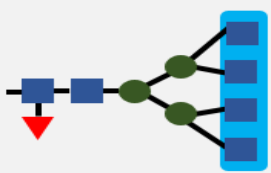

tetra-antennary

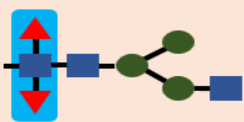

core fucosylation

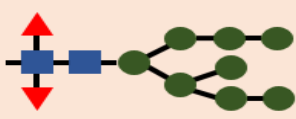

high mannose

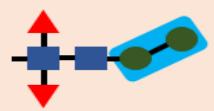

paucimannose

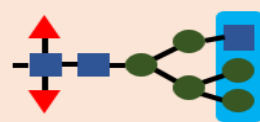

hybrid N-glycan

MAMMALIAN INSECT

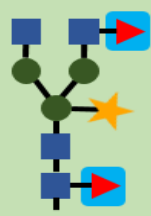

fucosylation

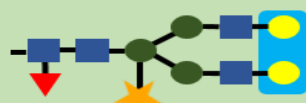

galactosylation

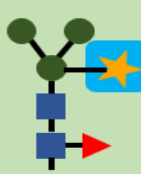

xylosylation

high mannose

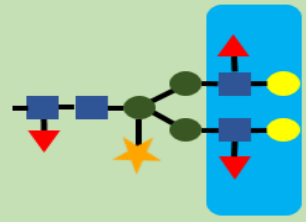

Lewis A-structure

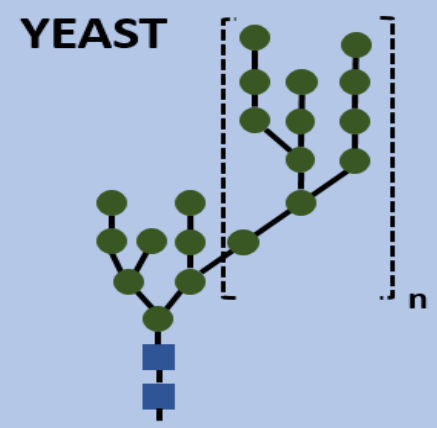

hypermannose

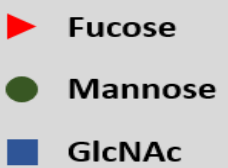

Galactose

Sialic acid

Xylose

This article is protected by copyright. All rights reserved. 
Keywords: Expression System, Post-translational Modification, Cell Engineering, CRISPR, Chinese Hamster Ovary

\section{Introduction}

The demand for recombinant biopharmaceuticals is steadily increasing and so does the proportion of molecules which require post-translational modifications (PTMs), such as monoclonal antibodies (mAbs) and blood factors (Walsh, 2014). With increasing size of the desired product, the amount of PTMs is often also increasing, giving rise to highly complex proteins. Correct PTMs, in particular N-glycosylation, can be essential for in vivo function and appropriate plasma half-life and to prevent immunological reactions after injection (Lai et al., 2018; Liu, 2015). While non-glycosylated drugs are therefore mostly produced in bacteria and yeast (Demain \& Vaishnav, 2009), glycosylated proteins require expression in mammalian cell lines. Thus, the rising number of approved biopharmaceuticals produced in mammalian expression systems aligns with the trend for a growing need for proper PTMs and other quality attributes. Nevertheless, microbial production is quantitatively still dominating. As reviewed previously, both mammalian and non-mammalian expression systems provide certain advantages, but also challenges (Adrio \& Demain, 2010; Demain \& Vaishnav, 2009). At the same time, plant-based and insect cell expression systems are catching up slowly.

While other human-like PTMs, such as gamma $(\gamma)$-carboxylation, phosphorylation and tyrosine sulfation can also be challenging during the production of therapeutic proteins, the most critical quality attribute is glycosylation, as indicated by the available documents from regulatory agencies across the world, e.g. the US Food and Drug Administration (FDA) and the European Medicines Agency (EMA) (EMEA, 2014a; EMEA, 2014b; FDA, 2012a; FDA, 2012c; FDA,

This article is protected by copyright. All rights reserved. 
2012b; FDA, 2014). Many cell platforms were therefore engineered towards human-like glycosylation (Stavenhagen et al., 2018). For certain proteins, untypical N-glycosylation may also be beneficial, e.g. Immunoglobulin G (IgG) with Man3GlcNAc2 trimannosyl chitobiose units for patients with systemic lupus erythematosus (Lood et al., 2012). The increase of characterized and sequenced host cell platforms as well as the advent of efficient genetic engineering tools recently has increased the available possibilities to speed up the process of producing protein products with high quality. In this review we discuss (i) the variety of expression platforms and their strengths and drawbacks, (ii) the available genetic engineering tools and (iii) a comprehensive retrospect of successful synthetic biology approaches to enhance product quality.

\section{Available expression platforms for different biopharmaceuticals}

Nowadays, numerous pro- and eukaryotic cells are available for the expression of biopharmaceuticals at industrial scale. These expression platforms can be mainly grouped into mammalian, bacteria, yeast, plant and insect systems (Schmidt, 2004; Karg \& Kallio, 2009). In addition to correct post-translational modification of the desired bioproduct, the production host cell type has to fulfill several requirements to meet the needs of bioprocessing. In detail, accessibility towards genetic engineering with an available molecular tool box, genomic stability, a functional secretory machinery, high rates of growth and productivity, easy bioprocess handling, scalability, and easy downstream purification are beneficial features of production platforms (Li, Vijayasankaran, Shen, Kiss, \& Amanullah, 2010). Additionally, the history and successful record of approvals of biopharmaceuticals produced in a certain cell type plays an important role when it comes to choosing the best-suited expression platform (Dumont,

This article is protected by copyright. All rights reserved. 
Euwart, Mei, Estes, \& Kshirsagar, 2016; Walsh, 2014). Characteristics of the here discussed expression systems are summarized and evaluated in Table 1.

\subsection{Mammalian expression platforms}

The class of mammalian expression platforms is divided into human and non-human derived cell lines, where non-human Chinese Hamster Ovary cells (CHO) are the most dominant manufacturing system (Lalonde \& Durocher, 2017). Human Embryonic Kidney 293 (HEK293) and CEVEC's Amniocyte Production (CAP) cells are examples of cell lines isolated from humans (Casademunt et al., 2012; Weis et al., 2018). The main advantage of human cell lines is the potential for identical human PTMs (Weis et al., 2018). On the other hand, non-human mammalian cell lines commonly used include CHO, Baby Hamster Kidney (BHK), and murine myeloma cells such as NS0, which all have, to a degree, the ability to perform human-like PTMs (Dumont et al., 2016). A major advantage, and this is in particular true for CHO, is the fact that they are more resistant towards adventitious contamination by human viruses, which results in enhanced safety and reduced viral inactivation and clearance efforts during downstream processing (Xu et al., 2011). Since sufficient protein modulation, folding and secretion can be achieved in mammalian cells, they are the preferred choice for the production of large and complex biopharmaceuticals (Dumont et al., 2016). In general, mammalian cells have large genomes consisting of more than 2 billion base pairs and forming a complicated structure of hetero- and euchromatin, which defines the regions that are actively transcribed or silenced (Feichtinger et al., 2016; Nozaki et al., 2017). Importantly, only 3\% of the entire genome consists of protein coding genes, which are structured into exons and introns while the remaining genome has regulatory function or contains non-coding genes (Feichtinger et al., 2016; Hernandez et al., 2019; Hubé \& Francastel, 2015). While the first human genome sequence This article is protected by copyright. All rights reserved. 
became available in 2001, the CHO genome was first sequenced in 2011 only (Venter et al., 2001; Xu et al., 2011). Since then, several reference genomes based on the Chinese Hamster have become available, with improved assembly quality (Brinkrolf et al., 2013; Lewis et al., 2013; Rupp et al., 2018) that now enable the design of evermore sophisticated tools for application in CHO cells (Amann et al., 2019; Marx et al., 2018). A broad molecular tool box as well as optimized cell culture techniques are accessible for the generation of transgenic mammalian production cell lines. Mammalian cells are mostly growing adherently in their native form, requiring complex media supplemented with Fetal Calf Serum (FCS) (Ho, Greene, Schmidt, \& Huang, 2004; Subedi, Johnson, Moniz, Moremen, \& Barb, 2015; Yao \& Asayama, 2017). Indeed, this generally increases the costs as well as the complexity of bioprocessing, especially during process scale up. These limitations are overcome by the use of CHO cells, which can be adapted to serum-free suspension growth with a doubling rate of 20-24 h depending on the process (Jayapal, Wlaschin, Hu \& Yap, 2007; Kunert \& Reinhart, 2016). In industrial scale, recombinant protein yields in the range of $\mathrm{g} / \mathrm{L}$ are obtained from CHO-based bioprocesses, while the production in other mammalian expression systems results in lower specific productivities and titers (Kunert \& Reinhart, 2016). To date, numerous biopharmaceuticals derived from mammalian cells are approved in the US and Europe. Especially the long list of approved therapeutics manufactured in $\mathrm{CHO}$ and processes that were established for this cell line during the last decades are emphasizing why $\mathrm{CHO}$ is the workinghorse of biopharma (Walsh, 2014). Nevertheless, genetic instability and intensive cell line generation as well as process development timelines are the major bottleneck of this system (Vcelar, Jadhav, et al., 2018; Vcelar, Melcher, et al., 2018; Wurm, 2004).

This article is protected by copyright. All rights reserved. 


\subsection{Bacterial expression platforms}

Bacterial expression systems, mainly Escherichia coli (E. coli), are widely used for the generation of smaller drugs, including hormones, growth factors and even more innovative therapeutic agents like peptibodies or peptide fragment crystallizable $(\mathrm{Fc})$ region fusions (Baumgarten, Jimmy Ytterberg, Zubarev, \& de Gier, 2018; Shimamoto, Gegg, Boone, \& Quéva, 2012). Unlike mammalian cells, bacterial microorganisms lack the ability to perform most PTMs, including glycosylation, which are essential for the production of active biopharmaceuticals (Brown et al., 2017; Ding et al., 2017). Additionally, correct protein folding, disulfide bond formation as well as proper secretion are not a given in most bacterial species leading to the formation of inclusion bodies (Martínez-Alonso, González-Montalbán, GarcíaFruitós, \& Villaverde, 2009). Using an appropriate signal sequence, the product of interest can be directed to the periplasm where a reducing environment allows protein oxidation for disulfide bond formation, thus enabling protein folding (Baumgarten et al., 2018; Miller \& Salama, 2018). However, this approach is only realizable in gram-negative bacteria (Miller \& Salama, 2018). Notably, Bacillus subtilis possess very efficient secretion routes due to the lack of the outer cell membrane as reviewed previously (Ling et al., 2007). Essentially, bacteria have small and uncomplex genomes counting less than 10 million base pair, which are very well characterized from as early as 1997 (Blattner et al., 1997). Rapid cell division in well less than an hour and growth in simple culture media are advantages of bacterial systems. Additionally, these characteristics enable a straightforward scale up in bioprocessing. However, bacterial endotoxins have to be removed carefully during bioprocessing to not cause immunogenic reactions in the patient later on and the above-mentioned lack of secretion make downstream purification more bothersome. Nevertheless, high expression levels, less expensive and less complex

This article is protected by copyright. All rights reserved. 
bioprocessing, as well as well characterized genetics with an extensive molecular tool box including inducible promoters are the benefits of manufacturing in bacteria (Sahdev, Khattar, \& Saini, 2008).

\subsection{Yeast expression platforms}

Pichia pastoris (P. pastoris) and Saccharomyces cerevisiae (S. cerevisiae) are the most important representatives of the yeast protein expression platforms. Due to cell compartmentalization, yeast microorganisms are capable of correct protein folding and further have the ability to perform typical eukaryotic PTMs including N- and, to some extent, O-linked glycosylation, phosphorylation, sulfation and ubiquitination as described and reviewed by others (Irani, Kerkhoven, Shojaosadati, \& Nielsen, 2015; Kim, Yoo, \& Kang, 2015; Ptacek et al., 2005). Based on the lack of human-like glycosylation, yeast strains are mainly used for the commercial manufacturing of smaller proteins, hormones and vaccines, with several products currently on the market (Cao et al., 2018; Mattanovich et al., 2011; Nielsen, 2013). Heterologous protein secretion can be achieved by the use of an appropriate signal peptide (Bae et al., 2015; Čiplys et al., 2015). In contrast to N-glycosylation in mammalian cells, yeast perform hypermannosylation, and lack the ability to generate sialylated N-glycans (Tang et al., 2016). Like bacterial host platforms, yeast strains have a small and well characterized genome of around 12 million base pairs, which can be modified by a large molecular and synthetic tool box with a large set of constitutive and inducible promoters (Jakočiūnas, Jensen, Jensen \& Keasling; 2018; Peter et al., 2018; Vieira Gomes et al., 2018). In general, recombinant production in yeast is moderately rapid and cost-efficient, whereas human virus-resistance and the absence of endotoxins are advantageous for downstream processing. Population doubling times within hours, simple medium compositions, and high recombinant protein yields are the reasons for the This article is protected by copyright. All rights reserved. 
good performance of yeast, thus, scalability of fermentations of transgenic yeast factories is sufficiently efficient (Vieira Gomes et al., 2018).

\subsection{Plant-derived expression platforms}

Plant-based expression systems were investigated for the production of biopharmaceuticals for many years, however, using plant cells rather than entire plants or parts of it is the current path forward (Chen \& Davis, 2016; Marsian \& Lomonossoff, 2016). Therefore, bioprocessing in plant cell lines e.g. tobacco cultivars Bright Yellow 2 (BY-2), Nicotiana tabacum 1 cells (NT-1), carrot or rice cells combines the advantages of plant farming and mammalian manufacturing procedures (Reuter, Bailey, Joensuu, \& Ritala, 2014). Reasonable doubling times (BY-2: 11 hours; NT-1: 1 day; rice cells: 1.5 days) in simple media, good upstream scalability, and resistance towards human pathogens are advantages of the system. However, complex downstream purification and low product yields remain major bottlenecks for plant hosts (Raven et al., 2015; Reuter et al., 2014; Su \& Lee, 2007). Plant platforms are used to express complex antibodies, low molecular weight products like enzymes, hormones, growth factors and cytokines or macromolecules like virus-like particles (VLPs) (Hellwig, Drossard, Twyman, \& Fischer, 2004; Marsian \& Lomonossoff, 2016). The genome size of different plant-derived cell lines varies significantly among the plant species. For instance, Nicotianca tabacum ( $N$. tabacum) and cells derived thereof have a genome of $\sim 4.5$ billion base pairs, whereas carrot cells have a smaller genome with 473 million nucleotides (Edwards et al., 2017, Iorizzo et al., 2016). The molecular tool box for plant cells is still limited, however, transformation of the gene of interest (GOI) is done by Agrobacterium infiltration in a well-established process (Leuzinger et al., 2013). So far, only one biopharmaceutical produced recombinantly in carrot-derived cells was approved by FDA (Marsian \& Lomonossoff, 2016; Zimran et al., 2011). In plants, the

This article is protected by copyright. All rights reserved. 
performance of PTMs, correct assembly and folding of complex therapeutics, as well as their secretion into the cell culture medium is possible (Raven et al., 2015). In terms of Nglycosylation, biopharmaceuticals generated from the plant-based system $N$. tabacum show plant-specific glycan structures and lack mammalian-specific sialic acids, which can result in immunogenicity and poor pharmacokinetics, respectively (Mercx et al., 2017; Raven et al., 2015). Another drawback of manufacturing in plant hosts is the relatively high level of bioproduct proteolysis induced by endogenous proteolytic enzymes, which indeed lower recombinant protein stability and yields (Mandal, Ahvari, Schillberg, \& Schiermeyer, 2016; Pillay, Schlüter, van Wyk, Kunert, \& Vorster, 2014; Strasser, Altmann, \& Steinkellner, 2014).

\subsection{Insect expression platforms}

For the production of recombinant biopharmaceuticals, insect cells are used in combination with baculovirus infection building the baculovirus-insect cell system (BICS) (Cox, 2012; Maghodia, Geisler, \& Jarvis, 2016). Trichoplusia ni from cabbage looper or the “gold standard” Spodoptera frugiperda (Sf), derived from fall armyworm, are examples of insect cell lines (Maghodia et al., 2016). Recently, efforts in whole-genome sequencing of insect cells were made resulting in the decoding of the Sf (451 Mb) as well as Trichoplusia ni (333 Mb) genomes (Chen et al., 2019; Nandakumar, Ma \& Khan, 2017). Since BICS is a "plug-and-play" system in which only the baculovirus vector has to be modified for each product prior to transduction of the insect cells, BICS is flexible, fast, and simple to use (Cox, 2012; Maghodia et al., 2016). Even the simultaneous production of several protein subunits is realizable (Roldão, Vicente, Peixoto, Carrondo, \& Alves, 2011). Moderate growth with a doubling time of 18-30 hours, modest expression, and difficulties during scale-up are reasons why production in insect cells is still quite rare, thus improvements in cell line development and bioprocessing are still challenges in

This article is protected by copyright. All rights reserved. 
this field (Chavez-Pena \& Kamen, 2018; Taticek, Choi, Phan, Palomares \& Shuler, 2008). Mainly vaccines and VLPs are generated from insect cell lines, where the first drug reached the biopharmaceutical market in 2009 only (Meghrous et al., 2015). With BICS, the turnover of producing and approving new vaccines is streamlined, thereby supporting the annual need of vaccines due to the seasonal and epidemic character of viruses (Mbewana, Mortimer, Pêra, Hitzeroth, \& Rybicki, 2015). As for most eukaryotic expression platforms, insect cells are capable to provide different PTM, whereas protein processing, folding, and secretion of secreted and membrane-bound products are limited and need to be initiated (Ailor \& Betenbaugh, 1999; Mandal et al., 2016). Therapeutics often remain insoluble and poorly processed in the cytoplasm of the insect cells (Ailor \& Betenbaugh, 1999). Similar to yeast expression systems, insect cells build simple, inconsistent paucimannose N-glycan structures (Chavez-Pena \& Kamen, 2018).

The low expression of most glycosyltransferases in combination with the presence of many active glycosidases leads to the incompatibility of generating human-like N-glycans in nonengineered insect cell lines (Geisler, Aumiller, \& Jarvis, 2008). Furthermore, reduced cell viability and declining titers are often observed due to proteolysis induced by baculovirusderived enzymes, especially in later phases of cultivation (Kim, Kramer, Hebert, Valdes, \& Bentley, 2007). Recently, an insect-specific virus contamination problem caused by rhabdovirus was reported. Although no evidence that the contamination might be harmful for humans was communicated so far, the biosafety of BICS has to be investigated (Maghodia et al., 2016).

\section{Reported complications within critical product quality attributes}

The number of approved biopharmaceuticals is increasing steadily with the predominant indications being cancer, inflammation-related conditions, hemophilia, metabolic disorders, diabetes and vaccinations against various infectious diseases (Walsh, 2014). Biopharmaceuticals This article is protected by copyright. All rights reserved. 
include mAbs, hormones, blood-related proteins, enzymes, vaccines, fusion proteins, growth factors and interferons, where each category requires distinct distribution and quality of necessary PTMs for proper pharmacodynamics and -kinetics and the absence of immunogenicity.

\subsection{Product glycosylation}

Glycosylation is the single most important PTM influencing product quality and may differ by sugar chain length, sequence as well as branching sites and branching numbers (Lis, Halina, \& Sharon, 1993; Werner, Kopp, \& Schlueter, 2007). Glycosylation is not only species- and cellspecific but also affected by culture conditions (Goochee \& Monica, 1990), causing differences between recombinant human (rh) glycoproteins and their endogenous counterparts and also impacting the reproducibility of production processes. An overview of the capabilities and limitations in building N-glycans by the different non-engineered production platforms discussed in this review is presented in Figure 1. The N-glycan composition can have tremendous impact on immunogenicity, pharmacodynamics and -kinetics of biopharmaceuticals (Liu, 2015). An example is the lacking ability of yeast, plants and insects to produce complex N-glycans with terminal sialylation (Harrison \& Jarvis, 2006; Strasser, Altmann, \& Steinkellner, 2014; Tanner \& Lehle, 1987), which often has negative consequences for pharmacokinetics (Sareneva, Cantell, Pyhälä, Pirhonen, \& Julkunen, 1993). Incomplete sialylation can cause mAb in vivo titers which are decreased by $50 \%$ compared to their fully sialylated counterpart 14 days post mAb injection (Naso et al., 2010). Unfavorable glycosylation is a major reason for the small number of approved biopharmaceuticals from yeast, plant and insect platforms (Walsh, 2014). Those biopharmaceuticals that require very specific and complex human-like $\mathrm{N}$-glycans are by necessity produced in mammalian expression platforms. Relevant examples include all mAbs as

This article is protected by copyright. All rights reserved. 
well as recombinant DNAse (enzyme), rh C1 inhibitor (rhC1INH) (plasma protein), and etanercept (IgG-Fc fusion protein) (Houel et al., 2014; Stavenhagen et al., 2018; van Veen et al., 2012; Zhang, Luo, \& Zhang, 2016). Furthermore, glycosylation is also particularly in the focus during the production of "biosimilar" biopharmaceuticals. The glycosylation profile of such biosimilars is aimed to mimic the "originator" biopharmaceutical and must not include immunogenic sugars.

The choice of cell platform from mammalian hosts can directly impact immunogenic properties of the therapeutic protein. As recently reported, rh coagulation factor (rhF) VIII expressed in BHK cells is more immunogenic than that produced in CHO cells (Lai et al., 2018). Rh erythropoietin (rhEPO) demands a high degree of sialylation and branching to achieve the desired biological potency (European Medicines Agency, 2006). As for rhFVIII, CHO platforms are the preferred host to achieve human-like N-glycosylation on rhEPO (Walsh, 2014).

Correct glycosylation is also important in the main product class of biopharmaceuticals, mAbs. The majority of mAbs are of IgG class and harbor a glycosylation site in the Fc region at amino acid position asparagine (Asn)-297, while a small proportion has an additional site in the Fab region. The composition of the sugar moieties often has a direct impact on pharmacokinetics, dynamics and immunogenicity (Liu, 2015) and is therefore a major target for cell engineering. The grade of mannosylation and sialylation can impact the pharmacokinetics of mAbs and overall efficacy (Liu, 2015). Importantly, the presence of core fucose reduces mAb binding to IgG Fc receptor IIIa, which negatively impacts antibody-dependent cell-mediated cytotoxicity (ADCC). With regards to complement-dependent cytotoxicity (CDC), low levels of terminal galactose on mAb were found to reduce CDC activity (Liu, 2015). Implications of the presence of non-human $N$-glycolylneuraminic acid (Neu5Gc) in biopharmaceuticals produced in mouse This article is protected by copyright. All rights reserved. 
myeloma cells furthermore underline the importance of glycosylation, but also the choice of expression platform (Ghaderi, Taylor, Padler-Karavani, Diaz, \& Varki, 2010). In comparison to mouse cell lines, the proportion of Neu5Gc in biopharmaceuticals from $\mathrm{CHO}$ platforms is relatively low, which was a major reason for the stop in use of mouse cell lines for human antibody production. An example for a product that does not need complex N-glycosylation, but instead requires high mannose $\mathrm{N}$-glycans is the recombinant enzyme glucocerebrosidase (GC). Produced in mammalian cell lines, N-glycans of purified GC are too complex and need downstream enzymatic treatment to ensure the biological uptake. Expression of rhGC in engineered carrot root cell culture makes this in vitro treatment unnecessary (Shaaltiel et al., 2007).

Recombinant hormones, growth factors and interferons such as insulin, rh growth hormone (rhGH), rh granulocyte-colony stimulating factor (rhG-CSF) and interferon- $\alpha$ (IFN- $\alpha$ ) demand rather uncomplex PTMs and therefore can be produced in E. coli or S. cerevisiae (Bönig et al., 2001; Walsh, 2014). An example is the E. coli-derived IFN- $\alpha$ with missing O-glycosylation, where the bioactivity is comparable to the human counterpart (Adolf, Kalsner, Ahorn, MaurerFogy, \& Cantell, 1991). Similarly, most recombinant vaccines do not need human-like PTMs to fulfill their functions and are predominantly produced in S. cerevisiae (Walsh, 2014). Nonetheless, the above examples clearly demonstrate that glycosylation is the single most important PTM of biopharmaceuticals.

\subsection{Product carboxylation, phosphorylation and sulfation}

Meeting certain N-glycosylation profiles is not the only PTM challenge faced by many biopharmaceutical producers. For some proteins of the class of blood related products, e.g. rhFIX

This article is protected by copyright. All rights reserved. 
and Protein C, $\gamma$-glutamyl carboxylation is crucial for efficacy and proper pharmacokinetics and represents a challenge during recombinant production (Berkner, 2008; Hansson \& Stenflo, 2005; Kaufman, 1998; Walsh, 2009). Since carboxylation activity is only reported within multicellular organisms, e.g. mammals and drosophila, biopharmaceuticals with the need for carboxylation have to be expressed in platforms derived of multicellular organisms, preferably from mammalian hosts (Bandyopadhyay et al., 2002).

Compared to N-glycosylation, phosphorylation and tyrosine sulfation are rather unexplored PTMs although phosphorylation is very common and more than 2,100 mammalian proteins are predicted to harbor sulfotyrosine (Moore, 2003). Correct tyrosine sulfation appears to not only modulate protein stability (Zhong et al., 2007), but also to influence the biological activity and binding affinities by affecting protein-protein interaction (Stone et al., 2009). Since natural $E$. coli and other prokaryotic expression platforms are not capable of performing tyrosine sulfation, mammalian cell systems are chosen to produce biopharmaceuticals that require sulfotyrosine, for example rhFVIII (Ezban, Vad, \& Kjalke, 2014).

\section{Genetic engineering tools}

To address problems with desired product quality, it is important to choose a suitable type of expression host that is capable of performing the required protein modifications without compromising product yield or other economic factors. To tackle lacking capabilities and improve host cell lines, or to specifically engineer them to address the requirements of a particular biopharmaceutical molecule, several genetic engineering tools are now available.

A prerequisite of targeted and fine-tuned genetic engineering is the availability of the genomic sequence of the host as well as the expression level of endogenous proteins and their function

This article is protected by copyright. All rights reserved. 
(Blattner et al., 1997; Jin et al., 2017; Kim, Rai, Zorraquino, \& Tagkopoulos, 2016; Nandakumar, Ma, \& Khan, 2017; Rupp et al., 2018; Sturmberger et al., 2016). Therefore, the rapid improvements in next-generation sequencing (NGS) techniques (Goodwin, McPherson, \& McCombie, 2016) and data generation via different -omics approaches that span all cellular levels from genome, epigenome, transcriptome, proteome and reactome, are the foundation for cell line editing to achieve optimal post-translational modulation of biopharmaceuticals (Brunk et al., 2016; Feichtinger et al., 2016; Stolfa et al., 2018). Classical engineering strategies rely on the overexpression (OE) or disruption of individual enzymes and proteins in pathways that have been shown to mediate naturally occurring PTMs (Chen et al., 2010; Shcherbakova, Lanzov, Ogawa, \& Filatov, 2000; Zhao \& McAlister-Henn, 1996). With this approach, the engineering targets are integrated randomly into the genome, resulting in heterogeneous cell populations and most likely flux imbalances in the cell (Lee, Aswani, Han, Tomlin, \& Dueber, 2013). It is typically difficult to achieve the precise expression level required for optimal protein processing and complicated to obtain tuned expression of multiple engineered enzymes. However, the rapid rise in published -omics data and functional studies opens the horizon for complex engineering strategies that target not only the $\mathrm{OE}$ and knockout $(\mathrm{KO})$ of individual genes, but also the prediction and control of optimal expression levels or combinations of enzymes. These approaches, in combination with in silico tools such as genome scale metabolic modeling now enable engineering of entire pathways (Calmels, McCann, Malphettes, \& Andersen, 2019; Khodayari \& Maranas, 2016; Saitua, Torres, Pérez-Correa, \& Agosin, 2017; Schirmer et al., 2016; Yuan, Cheung, Hilbers, \& van Riel, 2016).

To support this strategy, several molecular editing tools are now available. Treating cells with non-coding RNAs (ncRNAs) like small hairpin RNA (shRNA), microRNA or small interfering

This article is protected by copyright. All rights reserved. 
RNA (siRNA) is one way to control the transcriptomic level without affecting the genome (Fischer et al., 2014; Inwood, Betenbaugh, \& Shiloach, 2018; Kseniya Gavrilov, 2012; Wu, Shopsowitz, \& Hammond, 2016). These RNA molecules can either bind the mRNA target perfectly resulting in direct mRNA cleavage or with incomplete complementarity leading to translational repression and mRNA degradation (Agrawal et al., 2003). Thus, both mechanisms induce down regulation of target protein translation. Since engineering by microRNA or RNA interference (RNAi) approaches impacts the post-transcriptional cell state, the resulting effect is only temporary as long as the RNA molecules are present in the cells. Furthermore, some ncRNAs have multiple targets, which could be advantageous when multiple enzymes need to be altered simultaneously, but might also result in undesired side-effects (Lam, Chow, Zhang, \& Leung, 2015). For permanent manipulation of the genome, genome editing methods including meganucleases, zinc finger nucleases (ZFN) and transcription activator-like effector nucleases (TALEN) have emerged in the field quite some time ago. First genome editing experiments using ZFN were performed from 1996-2003 with an expanded application of ZFNs onwards, whereas TALENs entered the cell line engineering area in 2009/2010 only (Bibikova, Beumer, Trautman \& Carroll, 2003; Boch et al., 2009; Doudna \& Charpentier, 2014). These endonucleases can be programmed to build a DNA-enzyme-complex at any desired location in the genome inducing a double-stranded-break (DSB), which will be repaired by the cell's own mechanisms (Epinat et al., 2003; Kim, Lee, Kim, Cho, \& Kim, 2009; Miller et al., 2011). DSBs are either corrected by the error-prone non-homologous end joining (NHEJ) pathway resulting in small insertions/deletions (InDels) of nucleotides, thus, most likely in a frame-shift/loss-offunction mutation (Anthony J. Davis, 2013) or, if a suitable homology-mediating template is present, the DNA cut is repaired through the homology directed repair (HDR) pathway (Liang,

This article is protected by copyright. All rights reserved. 
Han, Romanienko, \& Jasin, 1998). Inducing the NHEJ mechanism is the preferred way if the aim is to $\mathrm{KO}$ a gene and the corresponding function, whereas initiating HDR is the method of choice to introduce new sequences into the host's genome (Sakuma et al., 2015; Santiago et al., 2008). In contrast to NHEJ, sequence knockin (KI) via HDR occurs at a much lower frequency in most if not all available expression systems (Heyer, Ehmsen, \& Liu, 2010; Miyaoka et al., 2016). Meganucleases, TALENs and ZFNs are protein-based genome engineering techniques. Therefore, for each target site new proteins have to be designed and produced, thus making their application time-consuming, expensive and laborious (Mali et al., 2013). The clustered regularly interspaced short palindromic repeats (CRISPR) system has recently emerged the field as an alternative tool. In nature, the RNA-protein-complex is part of the adaptive immune system of different bacterial strains to protect these from an infection caused by bacteriophages (Jinek et al., 2012). The original tool consists of the CRISPR-associated (Cas) endonuclease - with Cas9 from Streptococcus pyogenes as the most extensively used derivative - and a short RNA molecule, which is guiding the CRISPR enzyme to any DNA sequence of interest to specifically induce a molecular change at the 5'-prime region upstream of a protospacer adjacent motif (PAM). The later is an essential component for CRISPR activity and target recognition (Sternberg, Redding, Jinek, Greene, \& Doudna, 2014). The guide RNA (gRNA) molecule consists of two parts: (I) a CRISPR RNA (crRNA) sequence containing the variable target sequence (20 nt) followed by a repetitive part, and (II) a trans-acting CRISPR RNA (tracrRNA) sequence, which binds the crRNA repeats by complementarity (Karvelis et al., 2013). By doing so, a hairpin structure is formed leading to the attraction of the CRISPR enzyme (Fu, Sander, Reyon, Cascio, \& Joung, 2014). In 2012, Jinek et al. implemented a synthetic whole-in-one transcribed single guide RNA (sgRNA) for CRISPR/Cas9 (Jinek et al., 2012). Since only the

This article is protected by copyright. All rights reserved. 
guide sequence of the molecule has to be modified for each new target gene the technology is very flexible, easy to handle, and the application forms are diverse (Ul Ain, Chung, \& Kim, 2015). By the synchronous delivery of a sgRNA pair, entire gene bodies and also non-coding regions can be removed from the cell allowing proper gene function characterization without potential interference of truncated protein versions and also enabling the study of the non-coding part of the genome (Bydlinski et al., 2018; Raab et al., 2019; Schmieder et al., 2017; Zheng et al., 2014). So far, CRISPR/Cas9 has successfully been used in a wide range of organisms and cell lines for genome alteration by stable gene $\mathrm{KO}$ or KI. Additionally, reversible gene activation as well as repression can be achieved by using a catalytically dead Cas9 (dCas9) fused to an effector domain (Qi et al., 2013). Currently this technique enables for instance gene transcription activation or deactivation by de- or methylation of $\mathrm{CpG}$ islands within a promoter, or silencing by targeting transcription interfering proteins to a specific genome region (Liu et al., 2016; O’Geen et al., 2017; Xiong et al., 2019; Xu et al., 2016). Overall, powerful engineering tools and augmented host sequence precision and availability enable the targeting of DNA and RNA sequences to improve the capacity for post-translational modification of biopharmaceuticals in diverse production platforms.

\section{Genetic engineering to improve product quality attributes}

Traditional approaches to improve product quality depend on selection of the best performing clone, followed by medium and process design in addition to in vitro treatment of the purified therapeutic protein (Fan, Kildegaard, \& Andersen, 2017; Friedman et al., 1999). Depending on the medium additives and enzymes for in vitro treatments, these strategies are rather expensive, especially at production scales. With the previously described genetic tools, it is however

possible to change product quality via targeted engineering of the production host (Walsh, 2010).

This article is protected by copyright. All rights reserved. 
In this section, we describe selected examples of cell line engineering that contributed to improved product quality in eukaryotic and prokaryotic expression platforms. All described engineering examples are summarized in Table 2, categorized by the respective PTM.

\subsection{N-glycosylation}

\subsubsection{CHO, the main representative of mammalian expression platforms}

A major strength of $\mathrm{CHO}$ cells is their capability to produce biopharmaceuticals with human-like $\mathrm{N}$-glycans. However, there are attempts to engineer $\mathrm{CHO}$ towards a fully humanized $\mathrm{N}$ glycosylation profile comprising e.g. human-type alpha-2,6-sialylation or bisecting N-glycans. Notably, a small proportion of CHO N-glycans consists of Neu5Gc, which is immunogenetic for humans. Knockdown (KD) of Cytidine Monophospho-N-Acetylneuraminic Acid Hydroxylase (CMAH) with antisense RNA (asRNA) reduced the formation of Neu5Gc on host cell proteins (HCP) (Chenu et al., 2003).

Other approaches to transform $\mathrm{CHO} \mathrm{N}$-glycosylation into human $\mathrm{N}$-glycosylation include the expression or activation of the ST6 beta ( $\beta$ )-Galactoside alpha (a)-2,6-Sialyltransferase (ST6GAL) 1, which is encoded in the CHO genome without being active (Xu et al., 2011). Possibilities to generate $\mathrm{CHO}$ cell lines with humanized sialyation profiles include $\mathrm{OE}$ of ST6GAL1 cDNA or stable, but reversible, endogenous ST6GAL1-activation via epigenetic editing with CRISPR (Amann et al., 2019; Marx et al., 2018; Raymond et al., 2012).

Besides approaches towards humanized N-glycans, it is well known that certain sugar residues can improve the activity and/or serum half-life of particular biopharmaceuticals. A well-known example therefore is the $\mathrm{KO} / \mathrm{KD}$ of Fucosyltransferase 8 (FUT8) to reduce mAb core-

This article is protected by copyright. All rights reserved. 
fucosylation for significantly enhanced ADCC, which was achieved by homologous recombination and by applying different genetic engineering tools (including ZFN, CRISPR and siRNA) (Malphettes et al., 2010; Mori et al., 2004; Ronda et al., 2014; Yamane-Ohnuki et al., 2004). Reducing core-fucosylation was also achieved by OE of the glycosyltransferase MGAT3, responsible for introducing bisecting sugar residues (Umaña, Jean-Mairet, Moudry, Amstutz, \& Bailey, 1999).

Similarly, the clearance rate of rhEPO in the human body is affected by the degree of sialylation, causing fast degradation of under-sialylated EPO in the liver (Monroe \& Huber, 1995). Zhang et al. reported enhanced IFN- $\gamma$ sialylation after sh- and siRNA silencing the genes N-Acetyl-aNeuraminidase (NEU) 1 and 3, making them promising KO targets to generate a host cell for the production of highly-sialylated EPO (Zhang, Koskie, Ross, Kayser, \& Caple, 2010).

To address heterogeneous product $\mathrm{N}$-glycosylation in mammalian cells, which is particularly a problem in CHO cell lines, different groups applied ZFN-technology and CRISPR/Cas9 for simultaneous multiplexing of several target genes. The researchers successfully engineered CHO cells for homogeneous N-glycans on biopharmaceuticals and additionally investigated the impact of the generated gene disruptions on cell cultivation performance. To establish such homogenous N-glycans, multiple glycosyltransferases were disrupted via CRISPR/Cas9 or ZFN by either introducing InDels or by removing the complete gene sequence (Amann et al., 2018; Amann et al., 2019; Bydlinski et al., 2018; Yang et al., 2015). For a detailed insight into CHO N-glycan engineering we refer to a recently published review (Tejwani, Andersen, Nam, \& Sharfstein, 2018).

This article is protected by copyright. All rights reserved. 
Another successful engineering attempt introduced a plant-derived $\beta 1,2$-Xylosyltransferase (XYLT) into a CHO cell line to improve vaccine efficacy via N-xylosylation (Sandig et al., 2017), emphasizing that the transfer of certain glycosylation genes between species can result in promising PTM of biopharmaceuticals. The above examples underline that $\mathrm{N}$-glycan engineering in $\mathrm{CHO}$ cells is rather complex and highly dependent on the target protein and its pharmacokinetic requirements, yet a variety of desired structures can be tailored for an increasing number of biopharmaceuticals by glycosyltransferase gene KO, gene activation, gene KI or a combination thereof.

\subsubsection{Bacterial expression platforms}

Many bacterial expression systems, including E. coli, are incapable of protein glycosylation. However, researchers identified bacteria that have this ability (Castric, 1995; Szymanski, Yao, Ewing, Trust, \& Guerry, 1999; Thibault et al., 2001) and were able to transfer it into the industrially relevant E. coli (Wacker, 2002), showing for the first time that bacteria can be an alternative source for recombinant glycoproteins. While this first study produced bacterial Nglycans with great structural difference to their eukaryotic counterparts, a more advanced study reported that OE of yeast N-Acetylglucosaminyltransferase (ALG) 1, 2, 13 and 14 resulted in eukaryotic N-glycans on single-chain variable fragment (scFv) in E. coli (Valderrama-Rincon et al., 2012). This system can be used as a starting point to create novel glycoconjugates within bacterial expression platforms.

\subsubsection{Yeast expression platforms}

Yeast high-mannose N-glycans are often engineered towards more human-like N-glycans by first decreasing high-mannose proportions and then introducing genetic elements for complex N-

This article is protected by copyright. All rights reserved. 
glycosylation. First, hyper-mannosylation is eliminated by disruption of $\alpha-1,6-$ Mannosyltransferases (OCH1), ALG3 and ALG11 (De Pourcq, Tiels, Van Heck, Geysens, Vervecken, \& Callewaert, 2012; Jacobs, Geysens, Verveck, Contreras, \& Callewaert, 2009; Nasab, Aebi, Bernhard, \& Frey, 2013; Wang, Song, Wang, \& Qiu, 2013) or expressing Mannosidase (MAN) genes (De Pourcq, Tiels, Van Heck, Geysens, Vervecken, \& Callewaert, 2012). In the second step, glycosyltransferases, -transporters and sugar-synthesis enzymes are introduced (e.g. N-Acetylglucosaminyltransferase (GNT) and II, $\beta$-1,4-Galactosyltransferase (B4GALT) 1, ST6GAL, Glucosamine (UDP-N-Acetyl)-2-Epimerase (GNE), Cerebroside Sulfotransferase (CST)). Based on this strategy, Hamilton and co-workers introduced 14 elements and reported yeast strains producing complex glycoproteins with $>90 \%$ terminal sialylation (Hamilton et al., 2006). Yet, there are no biopharmaceuticals marketed, which are produced in engineered yeast platforms with humanized glycosylation. A possible reason therefore could be that human glycosylation, which is very far from the endogenous yeast glycosylation, interferes with yeast cell growth, resulting in low titers and therefore making manufacturing unprofitable.

Besides engineering towards human-like sugar residues, the reduction of N-glycan macroheterogeneity to ensure homogeneous products is also of major interest. OE of DolichylDiphosphooligosaccharide Protein Glycosyltransferase Subunit STT3 (STT3D) was shown to increase site occupancy and therefore reduce macro-heterogeneity during the production of rh Granulocyte-macrophage colony-stimulating factor (GM-CSF) and mAbs (Choi, et al., 2012).

This article is protected by copyright. All rights reserved. 


\subsubsection{Plant-derived expression platforms}

Plants contain $\beta$-hexosaminidases, which give rise to $\mathrm{N}$-glycan structures with terminal mannoses (Altmann, 2006; Choi, et al., 2012) and thus are far from their human counterparts. However, this is not only a drawback, but can be used for the production of biopharmaceuticals with efficient drug internalization by mannose receptors e.g. in Gaucher's disease patients (Strasser et al., 2014). One approved drug for Gaucher's disease, rhGC (taliglucerase alfa), is produced in carrot root cell culture with mainly xylosylated paucimannose N-glycans (Shaaltiel, et al., 2007; Tekoah et al., 2013). Non-engineered plants create the possibly immunogenic sugar residues $\beta 1$,2-xylose and core $\alpha 1,3$-fucose (Altmann, 2006) and can be engineered to lack the two sugar residues via KO/KD strategies. The use of RNAi resulted in the production of rhGC in Nicotiana benthamiana ( $N$. benthamiana) without immunogenic sugar residues (Limkul et al., 2016) and several mAb formats with engineered N-glycans were produced with the help of siRNA (Cox et al., 2006), CRISPR/Cas9 (Mercx et al., 2017) and RNAi technologies (Strasser et al., 2008.).

Yet, the rather simple plant glycosylation-machinery brings an important advantage. After removing all golgi-resident glycosyltransferases, single- or step-wise introduction of human glycosyltransferases allows the production of biopharmaceuticals with, compared to mammalian platforms, very homogeneous glycoforms (Strasser et al., 2014). Such biopharmaceuticals with defined sugar residues are extremely valuable for investigating the impact of $\mathrm{N}$-glycans on

protein functions. In addition, the above approach supports the understanding of the role of glycosyltransferases, allowing the selection of targets for $\mathrm{OE}$ or $\mathrm{KO}$ to engineer cell platforms with homogeneous and selected N-glycan profiles.

This article is protected by copyright. All rights reserved. 


\subsubsection{Insect expression platforms}

OE of human glycosyltransferases MGAT2, B4GALT and ST6GAL1 has been shown to reduce insect-typical oligo- and paucimannose residues and to introduce complex type N-glycans on recombinant proteins produced in insect cell lines (Hollister, Grabenhorst, Nimtz, Conradt, \& Jarvis, 2002; Kato et al., 2017). As for previously described expression systems, CRISPR tools are also used for insect cell lines to design N-glycans more similar to their human counterparts. One example is the disruption of $\beta-\mathrm{N}$-Acetylglucosaminidase (GalNAc) / fused lobes gene (FDL) to produce EPO with reduced oligo- and paucimannose structures in Sf9 cells (MabashiAsazuma \& Jarvis, 2017). As in yeast expression platforms, biopharmaceuticals from engineered insect-cell lines with humanized glycosylation are not yet found on the market. It can be speculated that the introduced human glycosylation, which is very distinct from the endogenous insect glycosylation, impacts insect cell growth negatively and therefore results in unprofitable manufacturing due to low titers.

\subsection{O-glycosylation}

Similar to N-glycosylation, O-glycosylation is a very common PTM in mammalian cells, yeast and plants where different types of O-glycosylation (e.g., O-linked fucose, glucose, mannose, xylose, or GalNAc) have been described on secreted proteins (Bennett et al., 2012). Immunoglobulin A (IgA) class molecules, rhEPO and Etanercept are examples of therapeutic proteins with O-glycosylation. However, the contribution of O-glycan moieties to therapeutic

properties is still not well understood, and suitable targets for O-glycan engineering are more

This article is protected by copyright. All rights reserved. 
difficult to identify than those for $\mathrm{N}$-glycan engineering as reviewed previously (Dicker \& Strasser, 2015).

In mammals, numerous and often differentially expressed glycosyltransferases give rise to complex O-glycan pathways and highly heterogeneous O-glycans (Kong et al., 2015; Taschwer et al., 2012; Yang et al., 2014). In contrast, O-glycan patterns from non-mammalian cell platforms are often more simple and less heterogeneous, allowing for the expression of proteins where non-human like O-glycans are acceptable (Hermeling, Crommelin, Schellekens, \& Jiskoot, 2004). To replace such rather uncomplex O-glycosylation structures in S. cerevisiae and plants, researchers successfully built up different core O-glycans by de novo engineering (Amano et al., 2008; Castilho et al., 2012; Dicker et al., 2016; Yang et al., 2012). For some products, the O-mannosylation of $P$. pastoris is undesired and can be counteracted by $\mathrm{OE}$ of an $\alpha$-mannosidase, enabling further elongation with mammalian-type modifications as reported by Hamilton et al. (Hamilton et al., 2013).

Engineering of O-glycosylation in mammalian cell lines mostly aims to either simplify the sugar moieties, to reduce product heterogeneity, or to design distinct O-glycans for superior protein functions. Yang et al. reported decreased O-glycan heterogeneity after disruption of Core 1 Synthase Glycoprotein-N-Acetylgalactosamine 3- $\beta$-Galactosyltransferase 1 (C1GALT1) Specific Chaperone 1 (COSMC) and Protein O-Linked Mannose N-Acetylglucosaminyltransferase 1 ( $\beta 1,2-)$ (POMGNT1) (Yang et al., 2014), whereas other groups achieved engineering of defined and elongated O-glycans in CHO (Lindberg et al., 2013; Liu, Jin, Cherian, Karlsson, \& Holgersson, 2015). Within prokaryotes, the rising field of bacterial glycoengineering could help to produce vaccine glycoconjugates with immunogenic bacterial glycans, as discussed in a previous review (Yates, Mills, \& DeLisa, 2018).

This article is protected by copyright. All rights reserved. 
As outlined in the section above, existing engineering strategies can be developed to promote immunogenic effects e.g. for vaccine production or to enable the construction of expression platforms for biopharmaceuticals with decreased O-glycan heterogeneity and defined O-glycan structures, however, the identification of suitable engineering targets is challenged by the presence of a vast number of O-glycosyltransferases and transferase-isoforms.

\subsection{Carboxylation}

Efficient $\gamma$-carboxylation of recombinant proteins is another challenge in the production of human-like PTMs. Similar to N-glycosylation, $\gamma$-carboxylation currently requires the use of mammalian cell platforms. Correct carboxylation is of exceptional importance to obtain high yields and functional molecules, especially in the context of vitamin K-dependent coagulation factor production (Vatandoost \& Pakdaman, 2016). Most difficult-to-express clotting factors except for FVIII and Von Willebrand Factor - are carboxylated by the vitamin K-dependent $\gamma$ carboxylation mechanism, as reviewed by Kumar in 2015 (Kumar, 2015). In 2005, Wajih et al. achieved an almost 3-fold increase in carboxylated rhFIX by OE of Vitamin K Epoxide Reductase Complex Subunit 1 (VKORC1), while OE of $\gamma$-carboxylase lead to the inhibition of functional rhFIX production in BHK cells (Wajih, Hutson, Owen, \& Wallin, 2005). One year later, the same research group engineered BHK21 cells by siRNA-based downregulation of calumenin, an inhibitor of the $\gamma$-carboxylation system, by $\sim 80 \%$. As a result, the rhFIX produced was $80 \%$ more functionally active compared to the untreated control (Wajih, Hutson, \& Wallin, 2006). Although it is known that Drosophila melanogaster and S2 cells derived from this insect express $\gamma$-Glutamyl Carboxylase (GGCX) and have the ability to process vitamin K, successful blood coagulation factor manufacturing has not been shown in these systems yet. Recently, coexpression of mammalian GGCX, VKORC1 and/or Protein Disulfide Isomerase Family A

This article is protected by copyright. All rights reserved. 
Member 2 (PDIA2) enabled recovery of active rhFVII in S2 cells (Nagahashi, Umemura, Kanayama, \& Iwaki, 2017).

\subsection{Phosphorylation}

Although protein phosphorylation is a very common PTM, it is predominantly associated with intracellular and not with therapeutic proteins (Walsh, 2010). However, proteomic and computational analysis revealed a large number of extracellular phosphorylated proteins including FIX (Kaushik, Henry, Clynes, \& Meleady, 2018; Yalak \& Vogel, 2012). Interestingly, recombinant FIX produced in CHO cells lacks phosphorylation (Rand, Kalafatis, \& Mann, 1994), which does not seem to affect clotting activity. The absence of proof for the importance of phosphorylation of therapeutic proteins might be one reason why there are few reports on improving the phosphorylation capacity in industrial expression platforms.

In contrast to mammalian cells, prokaryotes only have a low number of phosphorylated proteins (Enami \& Ishihama, 1984; Macek et al., 2008). The prokaryotic phosphorylation machinery can be enhanced by overexpressing product-specific protein kinases as presented in E. coli by Yue et al., where OE of Serine/Threonine-Protein Kinase 1 (SRPK1) increased pre-mRNA-splicing factor SF2 (ASF/SF2) phosphorylation (Yue, Ajuh, Akusjärvi, Lamond, \& Kreivi, 2000). Based on this approach it might also be possible to produce relevant therapeutic proteins with increased phosphorylation in E. coli or other expression platforms.

\subsection{Sulfation}

Only few recombinant biopharmaceuticals contain sulfation, and these are generally difficult to express due to the complexity of both the molecules and the modifications (Kumar, 2015;

This article is protected by copyright. All rights reserved. 
Suflita, Fu, He, Koffas, \& Linhardt, 2015). Eukaryotic expression platforms are capable of performing this kind of PTM (Zhao et al., 2017). Heparin is the most famous example of a sulfated difficult-to-express biopharmaceutical, but clotting factors rhFVIII and rhFIX also have tyrosine sulfation sites present (Garg et al., 2003; Kumar, 2015). Currently, Heparin-based drugs are obtained from animal-sources with a contamination crisis in 2008 in the US showing the need for a proper transgenic expression system. Whereas rhFVIII and rhFIX are mainly produced in CHO cells, BHK and HEK292 cells are also able to generate proteins with almost full sulfation (Swiech, Picanço-Castro, \& Covas, 2017). In the study of Datta et al. in 2013, CHO-S cells were engineered to express Golgi-targeted Heparan Sulfate Glucosamine 3-OSulfotransferase (HS3ST) 1 resulting in more 2-O, 6-O- and N-sulfo groups containing disaccharides in Heparan sulfate (HS), a molecule that shares the biosynthesis pathway with Heparin. Thus, the researchers aimed to generate Heparin from HS. Additionally, by the OE of the respective Golgi-bound sulfotransferase an increase of anti-Thrombin activity was achieved at the binding site (Datta et al., 2013). Zhang and colleagues overexpressed 2-O-Sulfotransferase (2-OST) as well as C5-epimerase ( $\mathrm{C}_{5}$-epi) in transgenic E.coli and used the generated enzymes to produce heparin by biochemical and chemical processing of HS (Zhang et al., 2015). The sulfated glycosaminoglycan chondroitin sulfate, which is used for the treatment of arthritis, was expressed in metabolically engineered E.coli BL21. To achieve the desired tyrosine sulfation, UDP-Glucose-4-Epimerase (kfo) genes A, C and F - enzymes/proteins as part of the capsular polysaccharide production - were transferred from the pathogenic E.coli strain K4 into the nonpathogenic strain BL21 (He et al., 2015).

This article is protected by copyright. All rights reserved. 


\section{Conclusion}

We described the diversity of expression platforms, which all represent certain advantages for the production of biopharmaceuticals. However, there is room for optimization since many PTMs are not naturally present in some hosts. The availability of sequence information and genetic tools for targeted engineering rapidly speeds up the generation of expression platforms capable of producing biopharmaceuticals with improved product qualities. KD and KO of one or several targets is achieved faster, cheaper and with more control than ever, whereas the OE of transgenes is still a frequent strategy to add certain functions to host cells. Additionally, the possibility to activate silent, or silence active endogenous genes by e.g. CRISPRa/CRISPRi is expanding the genetic toolbox, along with the development of synthetic biology strategies that enable fine-tuned expression of multiple genes in self-regulated circuits.

Unlike engineering towards improved glycosylation profiles, engineering other quality attributes such as carboxylation, phosphorylation, and sulfation is comparably underrepresented with only few targets described. However, novel CRISPR-based screening methods can promote the identification of new targets for improved phenotypes also for this challenge.

The identification and characterization of genes involved in the modification and quality of therapeutic proteins during their production is only one major challenge. The exploration of the relationship between different quality attributes, PTMs, as well as the actual in vivo function and mode of action of therapeutic proteins with specific modifications is of similar importance. While CHO is superior to the other platforms with regards to most PTMs, yeast is catching up with humanized N-glycosylation, and yeast-based therapeutic protein expression can be expected to become a serious contender in future manufacturing strategies (Gerngross, 2004). The main

This article is protected by copyright. All rights reserved. 
drawback of heavily engineered host cell lines that match the inherent capabilities found in $\mathrm{CHO}$ is that such complex engineering strategies are likely to result in an overburdening of the target cells with multiple engineered enzymes that need to be produced in addition to the product gene. This will likely reduce growth and biomass accumulation, thus taking away the main advantage of yeast compared to CHO: faster bioprocesses and higher cell densities.

In the authors`opinion, there is a trend towards the design of "cleaner" host cells where e.g. cellfree systems might enable a fully controlled design of product quality without interfering host cell pathways. Cell-free systems can be an alternative to generate therapeutic proteins with homogeneous and improved product quality based on cell lysates from E. coli and CHO (Brödel, Sonnabend, \& Kubick, 2014; Gurramkonda et al., 2018; Jaroentomeechai, et al., 2018). The main problems to be addressed here are the lack of compartmentalization, which makes the inherently sequential process of glycosylation difficult to achieve, as well as the poor scalability. However, these systems are extremely promising for small scale, point-of-care production of biopharmaceuticals, particularly in areas of the world where rapid supply or proper storage is difficult to achieve.

We conclude that the recently emerged genetic engineering tools contribute to a faster and more precise design of expression systems with improved product qualities. The trend of engineering expression platforms is particularly well exemplified by the vast amount of studies tailoring the glycosylation of different biopharmaceuticals. Although glycosylation is considered to be the single most important quality attribute of biopharmaceuticals, there is still a need for novel targets, in particular, to also expand the engineering for proper protein carboxylation, phosphorylation and sulfation.

This article is protected by copyright. All rights reserved. 


\section{Acknowledgement}

T.A and V.S. contributed equally to this review. The Novo Nordisk Foundation (NNF10CC1016517) supported this work. This work has been supported by the Austrian BMWFW, BMVIT, SFG, Standortagentur Tirol, Government of Lower Austria and Business Agency Vienna through the Austrian FFG-COMET- Funding Program. T.A., V.S., N.B., H.F.K. and M.R.A. are receiving funding from the European Union's Horizon 2020 research and innovation program under the Marie Sklodowska-Curie grant agreement No. 642663.

\section{Conflict of interest}

The authors declare no financial or commercial conflict of interest.

\section{References}

Adolf, G. R., Kalsner, I., Ahorn, H., Maurer-Fogy, I., \& Cantell, K. (1991). Natural human interferon- $\alpha 2$ isO-glycosylated. Biochemical Journal, 276(2), 511-518.

Adrio, J.-L., \& Demain, A. L. (2010). Recombinant organisms for production of industrial products. Bioengineered Bugs, 1(2), 116-131.

Agrawal, N., Dasaradhi, P. V. N., Mohmmed, A., Malhotra, P., Bhatnagar, R. K., \& Mukherjee, S. K. (2003). RNA Interference: Biology, Mechanism, and Applications. Microbiology and Molecular Biology Reviews: MMBR, 67(4), 657.

Altmann, F. (2007). The role of protein glycosylation in allergy. International Archieves of Allergy and Immunology, 142, 99-115.

This article is protected by copyright. All rights reserved. 
Amann, T., Hansen, A. H., Kol, S., Lee, G. M., Andersen, M. R., \& Kildegaard, H. F. (2018). CRISPR/Cas9-Multiplexed Editing of Chinese Hamster Ovary B4Gal-T1, 2, 3, and 4 Tailors N -Glycan Profiles of Therapeutics and Secreted Host Cell Proteins. Biotechnology Journal, 13(10), e1800111.

Amann, T., Hansen, A. H., Kol, S., Hansen, H. G., Arnsdorf, J., Nallapareddy, S., Voldborg, B., Lee, G. M., Andersen, M. R., Kildegaard, H. F. (2019). Glyco-engineered CHO cell lines producing alpha-1-antitrypsin and C1 esterase inhibitor with fully humanized Nglycosylation profiles. Metabolic Engineering, 52, 143-152.

Amano, K., Chiba, Y., Kasahara, Y., Kato, Y., Kaneko, M. K., Kuno, A., ... Narimatsu, H. (2008). Engineering of mucin-type human glycoproteins in yeast cells. Proceedings of the National Academy of Sciences of the United States of America, 105(9), 3232-3237.

Anthony J. Davis, D. J. C. (2013). DNA double strand break repair via non-homologous endjoining. Translational Cancer Research, 2(3), 130.

Bae, J.-H., Sung, B. H., Kim, H.-J., Park, S.-H., Lim, K.-M., Kim, M.-J., ... Sohn, J.-H. (2015). An Efficient Genome-Wide Fusion Partner Screening System for Secretion of Recombinant Proteins in Yeast. Scientific Reports, 5, 12229.

Bandyopadhyay, P. K., Garret, J. E., Shetty, R. P., Keate, T., Walker, C. S., Olivera, B. M., (2002) gamma-Glutamyl carboxylation: An extracellular posttranslational modification that antedates the divergence of molluscs, arthropods and chordates. Proc Natl Acad Sci, 99(3), 1264-1269.

This article is protected by copyright. All rights reserved. 
Baumgarten, T., Jimmy Ytterberg, A., Zubarev, R. A., \& de Gier, J.-W. (2018). Optimizing Recombinant Protein Production in the Escherichia coli Periplasm Alleviates Stress. Applied and Environmental Microbiology, 84(12), e00270-18.

Bennett, E. P., Mandel, U., Clausen, H., Gerken, T. A., Fritz, T. A., \& Tabak, L. A. (2012). Control of mucin-type O-glycosylation: a classification of the polypeptide GalNActransferase gene family. Glycobiology, 22(6), 736-756.

Berkner, K. L. (2008). Vitamin K-dependent carboxylation. Vitamins and Hormones, 78, 131156.

Bibikova, M., Beumer, K., Trautman, J. K., Carroll, D. (2003). Enhancing gene targeting with designed zinc finger nucleases. Science, 300, 764.

Blattner, F. R., Plunkett III, G., Bloch, C. A., Perna, N. T., Burland, V., Riley, M., ... Shao, Y. (1997). The Complete Genome Sequence of Escherichia coli K-12. Science, 277(5331), 1453-1462.

Boch, J., Scholze, H., Schornack, S., Landgraf, A., Hahn, S., Kay, S., Lahaye, T., Nickstadt, A., Bonas, U. (2001). Breaking the code of DNA binding specificity of TAL-type III effectors. Science, 326, 1509-1512.

Bönig, H., Silbermann, S., Weller, S., Kirschke, R., Körholz, D., Janssen, G., ... Nürnberger, W. (2001). Glycosylated vs non-glycosylated granulocyte colony-stimulating factor (GCSF)--results of a prospective randomised monocentre study. Bone Marrow Transplantation, 28(3), 259-264.

This article is protected by copyright. All rights reserved. 
Brinkrolf, K., Rupp, O., Laux, H., Kollin, F., Ernst, W., Linke, B., ... Borth, N. (2013). Chinese hamster genome sequenced from sorted chromosomes. Nature Biotechnology, 31(8), 694-965.

Brödel, A. K., Sonnabend, A., \& Kubick, S. (2014). Cell-free protein expression based on extracts from CHO cells. Biotechnology and Bioengineering, 111(1), 25-36.

Brown, C. W., Sridhara, V., Boutz, D. R., Person, M. D., Marcotte, E. M., Barrick, J. E., \& Wilke, C. O. (2017). Large-scale analysis of post-translational modifications in E. coli under glucose-limiting conditions. BMC Genomics, 18. https://doi.org/10.1186/s12864017-3676-8

Brunk, E., George, K. W., Alonso-Gutierrez, J., Thompson, M., Baidoo, E., Wang, G., ... Lee, T. S. (2016). Characterizing Strain Variation in Engineered E. coli Using a Multi-OmicsBased Workflow. Cell Systems, 2(5), 335-346.

Bydlinski, N., Maresch, D., Schmieder, V., Klanert, G., Strasser, R., \& Borth, N. (2018). The contributions of individual galactosyltransferases to protein specific N-glycan processing in Chinese Hamster Ovary cells. Journal of Biotechnology, 282, 101-110.

Calmels, C., McCann, A., Malphettes, L., \& Andersen, M. R. (2019). Application of a curated genome-scale metabolic model of $\mathrm{CHO}$ DG44 to an industrial fed-batch process. Metabolic Engineering, 51, 9-19.

Cao, J., Perez-Pinera, P., Lowenhaupt, K., Wu, M.-R., Purcell, O., de la Fuente-Nunez, C., \& Lu, T. K. (2018). Versatile and on-demand biologics co-production in yeast. Nature Communications, 9(1), 77.

This article is protected by copyright. All rights reserved. 
Casademunt, E., Martinelle, K., Jernberg, M., Winge, S., Tiemeyer, M., Biesert, L., ... Schröder, C. (2012). The first recombinant human coagulation factor VIII of human origin: human cell line and manufacturing characteristics. European Journal of Haematology, 89(2), 165.

Castilho, A., Neumann, L., Daskalova, S., Mason, H. S., Steinkellner, H., Altmann, F., \& Strasser, R. (2012). Engineering of Sialylated Mucin-typeO-Glycosylation in Plants. The Journal of Biological Chemistry, 287(43), 36518-36526.

Castric, P. (1995). pilO, a gene required for glycosylation of Pseudomonas aeruginosa 1244 pilin. Microbiology, 141 ( Pt 5), 1247-1254.

Chavez-Pena, C., \& Kamen, A. A. (2018). RNA interference technology to improve the baculovirus-insect cell expression system. Biotechnology Advances, 36(2), 443-451.

Chen, Q., \& Davis, K. R. (2016). The potential of plants as a system for the development and production of human biologics. F1000Research, 5. https://doi.org/10.12688/f1000research.8010.1

Chen, W., Yang, X., Tetreau, G., Song, X., Coutu, C., Hegedus, D., ... Wang, P. (2019). A highquality chromosome-level genome assembly of a generalist herbivore, Trichoplusia ni. Molecular Ecology Resources, 19(2), 485-496.

Chenu, S., Grégoire, A., Malykh, Y., Visvikis, A., Monaco, L., Shaw, L., ... Goergen, J.-L. (2003). Reduction of CMP-N-acetylneuraminic acid hydroxylase activity in engineered Chinese hamster ovary cells using an antisense-RNA strategy. Biochimica et Biophysica Acta, 1622(2), 133-144.

This article is protected by copyright. All rights reserved. 
Chen, X., Liang, Y., Hua, J., Tao, L., Qin, W., \& Chen, S. (2010). Overexpression of bacterial ethylene-forming enzyme gene in Trichoderma reesei enhanced the production of ethylene. International Journal of Biological Sciences, 6(1), 96-106.

Choi, BK., Warburton, S., Lin, H., Patel, R., Boldogh, I., Meehl, M., ... Sethuraman, N. (2012). Improvement of $\mathrm{N}$-glycan site occupancy of therapeutic glycoproteins produced in Pichia pastoris. Applied Microbiology and Biotechnology, 95(3), 671-682.

Chung, C. Y., Majewska, N. I., Wang, Q., Paul, J. T., Betenbaugh, M. J. (2017) SnapShot: Nglycosylation Processing Pathways across Kingdoms. Cell, 171(1), 258-258.e1.

Čiplys, E., Žitkus, E., Gold, L. I., Daubriac, J., Pavlides, S. C., Højrup, P., ... Slibinskas, R. (2015). High-level secretion of native recombinant human calreticulin in yeast. Microbial Cell Factories, 14, 165.

Cox, K. M., Sterling, J. D., Regan, J. T., Gasdaska, J. R., Frantz, K. K., Peele, C. G., ... Dickey, L. F. (2006). Glycan optimization of a human monoclonal antibody in the aquatic plant Lemna minor. Nature Biotechnology, 24(12), 1591-1597.

Cox, M. M. J. (2012). Recombinant protein vaccines produced in insect cells. Vaccine, 30(10), 1759-1766.

Datta, P., Li, G., Yang, B., Zhao, X., Baik, J. Y., Gemmill, T. R., ... Linhardt, R. J. (2013). Bioengineered Chinese hamster ovary cells with Golgi-targeted 3-O-sulfotransferase-1 biosynthesize heparan sulfate with an antithrombin-binding site. The Journal of Biological Chemistry, 288(52), 37308-37318.

This article is protected by copyright. All rights reserved. 
Demain, A. L., \& Vaishnav, P. (2009). Production of recombinant proteins by microbes and higher organisms. Biotechnology Advances, 27(3), 297-306.

De Pourcq, K., Tiels, P., Van Hecke, A., Geysens, S., Vervecken, W., \& Callewaert, N. (2012). Engineering Yarrowia lipolytica to produce glycoproteins homogeneously modified with the universal Man3GlcNAc2 N-glycan core. PloS One, 7(6), e39976.

De Pourcq, K., Vervecken, W., Dewerte, I., Valevska, A., Van Hecke, A., \& Callewaert, N. (2012). Engineering the yeast Yarrowia lipolytica for the production of therapeutic proteins homogeneously glycosylated with Man8GlcNAc2 and Man5GlcNAc2. Microbial Cell Factories, 11(1), 53.

Dicker, M., Tschofen, M., Maresch, D., König, J., Juarez, P., Orzaez, D., ... Strasser, R. (2016). Transient Glyco-Engineering to Produce Recombinant IgA1 with Defined N- and OGlycans in Plants. Frontiers Plant Science, https://doi.org/10.3389/fpls.2016.00018

Dicker, M., \& Strasser, R. (2015). Using glyco-engineering to produce therapeutic proteins. Expert Opinion on Biological Therapy, 15(10), 1501-1516.

Ding, N., Yang, C., Sun, S., Han, L., Ruan, Y., Guo, L., ... Zhang, J. (2017). Increased glycosylation efficiency of recombinant proteins in Escherichia coli by auto-induction. Biochemical and Biophysical Research Communications, 485(1), 138-143.

Doudna, J. A., Charpentier, E. (2014). Genome editing. The new frontier of genome engineering with CRISPR-Cas9. Science, 346(6213), 1258096.

This article is protected by copyright. All rights reserved. 
Dumont, J., Euwart, D., Mei, B., Estes, S., \& Kshirsagar, R. (2016). Human cell lines for biopharmaceutical manufacturing: history, status, and future perspectives. Critical Reviews in Biotechnology, 36(6), 1110-1122.

Edwards, K. D., Fernandez-Pozo, N., Drake-Stowe, K., Humphry, M., Evans, A. D., Bombarely, A., ... Mueller, L. A. (2017). A reference genome for Nicotiana tabacum enables mapbased cloning of homeologous loci implicated in nitrogen utilization efficiency. BMC Genomics, 18, 448.

EMEA. (2014a). EMEA guideline on similar biological medicinal products containing biotechnology-derived proteins as active substance: Quality issues. Retrieved from http://www.ebe-

biopharma.eu/uploads/Modules/Newsroom/ema:chmp:bwp:247713:2012.pdf

EMEA. (2014b). Guideline on similar biological medicinal products containing biotechnologyderived proteins as active substance: Non-clinical and clinical issues. Retrieved from http://www.ema.europa.eu/docs/en_GB/document_library/Scientific_guideline/2015/01/ WC500180219.pdf

Enami, M., \& Ishihama, A. (1984). Protein phosphorylation in Escherichia coli and purification of a protein kinase. The Journal of Biological Chemistry, 259(1), 526-533.

Epinat, J.-C., Arnould, S., Chames, P., Rochaix, P., Desfontaines, D., Puzin, C., ... Lacroix, E. (2003). A novel engineered meganuclease induces homologous recombination in yeast and mammalian cells. Nucleic Acids Research, 31(11), 2952-2962.

This article is protected by copyright. All rights reserved. 
European Medicines Agency. (2006). Annex to guideline on similar biological medicinal products containing biotechnology-derived proteins as active substance: Non-clinical and clinical issues. Guidance on similar medicinal products containing recombinant $\begin{array}{lll}\text { human } & \text { insulin. } & \text { Retrieved }\end{array}$ http://www.ema.europa.eu/docs/en_GB/document_library/Scientific_guideline/2009/09/ WC500003957.pdf

Ezban, M., Vad, K., \& Kjalke, M. (2014). Turoctocog alfa (NovoEight $\left.{ }^{\circledR}\right)--$ from design to clinical proof of concept. European Journal of Haematology, 93(5), 369-376.

Fan, Y., Kildegaard, H. F., \& Andersen, M. R. (2017). Engineer Medium and Feed for Modulating N-Glycosylation of Recombinant Protein Production in CHO Cell Culture. In Methods in Molecular Biology (pp. 209-226).

FDA. (2012a). Guidance for industry biosimilars: Questions and answers regarding implementation of the biologics price competition and innovation act of 2009. Retrieved from http://www.fda.gov/downloads/Drugs/Guidances/UCM273001.pdf

FDA. (2012b). Guidance for industry quality considerations in demonstrating biosimilarity to a $\begin{array}{llll}\text { reference } & \text { protein } & \text { product. } & \text { Retrieved }\end{array}$ http://www.fda.gov/downloads/drugs/guidancecomplianceregulatoryinformation/guidan ces/ucm291134.pdf

FDA. (2012c). Guidance for industry scientific considerations in demonstrating biosimilarity to a reference product.

Retrieved from 
http://www.fda.gov/downloads/drugs/guidancecomplianceregulatoryinformation/guidan ces/ucm291128.pdf

FDA. (2014). Guidance for industry clinical pharmacology data to support a demonstration of biosimilarity to a reference product. Retrieved from http://www.fda.gov/downloads/drugs/guidancecomplianceregulatoryinformation/guidan ces/ucm397017.pdf

Feichtinger, J., Hernández, I., Fischer, C., Hanscho, M., Auer, N., Hackl, M., ... Borth, N. (2016). Comprehensive genome and epigenome characterization of CHO cells in response to evolutionary pressures and over time. Biotechnology and Bioengineering, 113(10), 2241-2253.

Fischer, S., Buck, T., Wagner, A., Ehrhart, C., Giancaterino, J., Mang, S., ... Otte, K. (2014). A functional high-content miRNA screen identifies miR-30 family to boost recombinant protein production in CHO cells. Biotechnology Journal, 9(10), 1279-1292.

Friedman, B., Vaddi, K., Preston, C., Mahon, E., Cataldo, J. R., \& McPherson, J. M. (1999). A comparison of the pharmacological properties of carbohydrate remodeled recombinant and placental-derived beta-glucocerebrosidase: implications for clinical efficacy in treatment of Gaucher disease. Blood, 93(9), 2807-2816.

Fu, Y., Sander, J. D., Reyon, D., Cascio, V. M., \& Joung, J. K. (2014). Improving CRISPR-Cas nuclease specificity using truncated guide RNAs. Nature Biotechnology, 32(3), 279284.

This article is protected by copyright. All rights reserved. 
Garg, H. G., Yu, L., Hales, C. A., Toida, T., Islam, T., \& Linhardt, R. J. (2003). Sulfation patterns in heparin and heparan sulfate: effects on the proliferation of bovine pulmonary artery smooth muscle cells. Biochimica et Biophysica Acta, 1639(3), 225-231.

Geisler, C., Aumiller, J. J., \& Jarvis, D. L. (2008). A fused lobes gene encodes the processing beta-N-acetylglucosaminidase in Sf9 cells. The Journal of Biological Chemistry, 283(17), 11330-11339.

Gerngross, T. U. (2004). Corrigendum: Advances in the production of human therapeutic proteins in yeasts and filamentous fungi. Nature Biotechnology, 22(12), 1589-1589.

Ghaderi, D., Taylor, R. E., Padler-Karavani, V., Diaz, S., \& Varki, A. (2010). Implications of the presence of $\mathrm{N}$-glycolylneuraminic acid in recombinant therapeutic glycoproteins. Nature Biotechnology, 28(8), 863-867.

Goochee, C. F., \& Monica, T. (1990). Environmental Effects on Protein Glycosylation. Nature Biotechnology, 8(5), 421-427.

Goodwin, S., McPherson, J. D., \& McCombie, W. R. (2016). Coming of age: ten years of nextgeneration sequencing technologies. Nature Reviews. Genetics, 17(6), 333-351.

Gurramkonda, C., Rao, A., Borhani, S., Pilli, M., Deldari, S., Ge, X., ... Rao, G. (2018). Improving the recombinant human erythropoietin glycosylation using microsome supplementation in CHO cell-free system. Biotechnology and Bioengineering, 115(5), 1253-1264.

This article is protected by copyright. All rights reserved. 
Hamilton, S. R., Cook, W. J., Gomathinayagam, S., Burnina, I., Bukowski, J., Hopkins, D., ... Nett, J. H. (2013). Production of sialylated O-linked glycans in Pichia pastoris. Glycobiology, 23(10), 1192-1203.

Hamilton, S. R., Davidson, R. C., Sethuraman, N., Nett, J. H., Jiang, Y., Rios, S., ... Gerngross, T. U. (2006). Humanization of yeast to produce complex terminally sialylated glycoproteins. Science, 313(5792), 1441-1443.

Hansson, K., \& Stenflo, J. (2005). Post-translational modifications in proteins involved in blood coagulation. Journal of Thrombosis and Haemostasis: JTH, 3(12), 2633-2648.

Harrison, R. L., \& Jarvis, D. L. (2006). Protein N-glycosylation in the baculovirus-insect cell expression system and engineering of insect cells to produce "mammalianized" recombinant glycoproteins. Advances in Virus Research, 68, 159-191.

Hellwig, S., Drossard, J., Twyman, R. M., \& Fischer, R. (2004). Plant cell cultures for the production of recombinant proteins. Nature Biotechnology, 22(11), 1415-1422.

Hermeling, S., Crommelin, D. J. A., Schellekens, H., \& Jiskoot, W. (2004). Structureimmunogenicity relationships of therapeutic proteins. Pharmaceutical Research, 21(6), 897-903.

Hernandez, I., Dhiman, H., Klanert, G., Jadhav, V., Auer, N., Hanscho, M., ... Borth, N. (2019). Epigenetic regulation of gene expression in Chinese Hamster Ovary cells in response to the changing environment of a batch culture. Biotechnology and Bioengineering, 116(3), 677-692.

This article is protected by copyright. All rights reserved. 
He, W., Fu, L., Li, G., Andrew Jones, J., Linhardt, R. J., \& Koffas, M. (2015). Production of chondroitin in metabolically engineered E. coli. Metabolic Engineering, 27, 92-100.

Heyer, W.-D., Ehmsen, K. T., \& Liu, J. (2010). Regulation of homologous recombination in eukaryotes. Annual Review of Genetics, 44, 113-139.

Ho, L., Greene, C. L., Schmidt, A. W., \& Huang, L. H. (2004). Cultivation of HEK 293 cell line and production of a member of the superfamily of G-protein coupled receptors for drug discovery applications using a highly efficient novel bioreactor. Cytotechnology, 45(3), $117-123$.

Hollister, J., Grabenhorst, E., Nimtz, M., Conradt, H., \& Jarvis, D. L. (2002). Engineering the protein N-glycosylation pathway in insect cells for production of biantennary, complex N-glycans. Biochemistry, 41(50), 15093-15104.

Houel, S., Hilliard, M., Yu, Y. Q., McLoughlin, N., Martin, S. M., Rudd, P. M., ... Chen, W. (2014). N- and O-glycosylation analysis of etanercept using liquid chromatography and quadrupole time-of-flight mass spectrometry equipped with electron-transfer dissociation functionality. Analytical Chemistry, 86(1), 576-584.

Hubé, F., Francastel, C. (2015). Mammalian Introns: When the Junk Generates Molecular Diversity. International Journal of Molecular Sciences, 16(3), 4429-4452.

Inwood, S., Betenbaugh, M. J., \& Shiloach, J. (2018). Methods for Using Small Non-Coding RNAs to Improve Recombinant Protein Expression in Mammalian Cells. Genes, 9(1). https://doi.org/10.3390/genes9010025

This article is protected by copyright. All rights reserved. 
Iorizzo, M., Ellison, S., Senalik, D., Zeng, P., Satapoomin, P., Huang, J., ... Simon, P. (2016). A high-quality carrot genome assembly provides new insights into carotenoid accumulation and asterid genome evolution. Nature Genetics, 48(6), 657-66.

Irani, Z. A., Kerkhoven, E. J., Shojaosadati, S. A., \& Nielsen, J. (2015). Genome-scale metabolic model ofPichia pastoriswith native and humanized glycosylation of recombinant proteins. Biotechnology and Bioengineering, 113(5), 961-969.

Jacobs, P. P., Geysens, S., Vervecken, W., Contreras, R., \& Callewaert, N. (2009). Engineering complex-type N-glycosylation in Pichia pastoris using GlycoSwitch technology. Nature Protocols, 4(1), 58-70.

Jakočiūnas T., Jensen E. D., Jensen M. K., Keasling J. D. (2018). Assembly and multiplex genome integration of metabolic pathways in yeast using CasEMBLR. Methods in Molecular Biology, 1671, 185-201.

Jaroentomeechai, T., Stark, JC., Natarajan, A., Glasscock, CJ., Yates, LE., Hsu, KJ., ... DeLisa, MP. (2018). Single-pot glycoprotein biosynthesis using a cell-free transcriptiontranslation system enriched with glycosylation machinery. Nature Communications, 9, 2686.

Jayapal K.P., Wlaschin K.F., Hu W.S., Yap M.G. (2007). Recombinant protein therapeutics from CHO cells—20 years and counting. Chemical Engineering Progress, 103, 40-47.

Jinek, M., Chylinski, K., Fonfara, I., Hauer, M., Doudna, J. A., \& Charpentier, E. (2012). A programmable dual-RNA-guided DNA endonuclease in adaptive bacterial immunity. Science, 337(6096), 816-821.

This article is protected by copyright. All rights reserved. 
Jin, J., Zhang, H., Zhang, J., Liu, P., Chen, X., Li, Z., ... Cao, P. (2017). Integrated transcriptomics and metabolomics analysis to characterize cold stress responses in Nicotiana tabacum. BMC Genomics, 18(1), 496.

Karg, S. R., \& Kallio, P. T. (2009). The production of biopharmaceuticals in plant systems. Biotechnology Advances, 27(6), 879-894.

Karvelis, T., Gasiunas, G., Miksys, A., Barrangou, R., Horvath, P., \& Siksnys, V. (2013). crRNA and tracrRNA guide Cas9-mediated DNA interference in Streptococcus thermophilus. RNA Biology, 10(5), 841.

Kato, T., Kako, N., Kikuta, K., Miyazaki, T., Kondo, S., Yagi, H., ... Park, E. Y. (2017). NGlycan Modification of a Recombinant Protein via Coexpression of Human Glycosyltransferases in Silkworm Pupae. Scientific Reports, 7(1), 1409.

Kaufman, R. J. (1998). Post-translational modifications required for coagulation factor secretion and function. Thrombosis and Haemostasis, 79(6), 1068-1079.

Kaushik, P., Menry, M., Clynes, M., \& Meleady, P. (2018). The expression pattern of the phosphoproteome is significantly changed during the growth phases of recombinant CHO cell culture. Biotechnology Journal, 13(10), https://doi.org/10.1002/biot.201700221

Khodayari, A., \& Maranas, C. D. (2016). A genome-scale Escherichia coli kinetic metabolic model k-ecoli457 satisfying flux data for multiple mutant strains. Nature Communications, 7, 13806.

This article is protected by copyright. All rights reserved. 
Kim, E. J., Kramer, S. F., Hebert, C. G., Valdes, J. J., \& Bentley, W. E. (2007). Metabolic engineering of the baculovirus-expression system via inverse "shotgun" genomic analysis and RNA interference (dsRNA) increases product yield and cell longevity. Biotechnology and Bioengineering, 98(3), 645-654.

Kim, H. J., Lee, H. J., Kim, H., Cho, S. W., \& Kim, J.-S. (2009). Targeted genome editing in human cells with zinc finger nucleases constructed via modular assembly. Genome Research, 19(7), 1279-1288.

Kim, H., Yoo, S. J., \& Kang, H. A. (2015). Yeast synthetic biology for the production of recombinant therapeutic proteins. FEMS Yeast Research, 15(1), 1-16.

Kim, M., Rai, N., Zorraquino, V., \& Tagkopoulos, I. (2016). Multi-omics integration accurately predicts cellular state in unexplored conditions for Escherichia coli. Nature Communications, 7, 13090.

Kong, Y., Joshi, H. J., Schjoldager, K. T.-B. G., Madsen, T. D., Gerken, T. A., VesterChristensen, M. B., ... Clausen, H. (2015). Probing polypeptide GalNAc-transferase isoform substrate specificities by in vitro analysis. Glycobiology, 25(1), 55-65.

Kseniya Gavrilov, W. M. S. (2012). Therapeutic siRNA: Principles, Challenges, and Strategies. The Yale Journal of Biology and Medicine, 85(2), 187.

Kumar, S. R. (2015). Industrial production of clotting factors: Challenges of expression, and choice of host cells. Biotechnology Journal, 10(7), 995-1004.

This article is protected by copyright. All rights reserved. 
Kunert, D. R., Reinhart, D. (2016). Advances in recombinant antibody manufacturing. Applied Microbiology and Biotechnology, 100, 3451-3461.

Lai, J. D., Swystun, L. L., Cartier, D., Nesbitt, K., Zhang, C., Hough, C., ... Lillicrap, D. (2018). N-linked glycosylation modulates the immunogenicity of recombinant human factor VIII in hemophilia A mice. Haematologica. https://doi.org/10.3324/haematol.2018.188219

Lalonde, M.-E., \& Durocher, Y. (2017). Therapeutic glycoprotein production in mammalian cells. Journal of Biotechnology, 251, 128-140.

Lam, J. K. W., Chow, M. Y. T., Zhang, Y., \& Leung, S. W. S. (2015). siRNA Versus miRNA as Therapeutics for Gene Silencing. Molecular Therapy. Nucleic Acids, 4(9), e252.

Lee, M. E., Aswani, A., Han, A. S., Tomlin, C. J., \& Dueber, J. E. (2013). Expression-level optimization of a multi-enzyme pathway in the absence of a high-throughput assay. Nucleic Acids Research, 41(22), 10668-10678.

Leuzinger, K., Dent, M., Hurtado, J., Stahnke, J., Lai, H., Zhou, X., \& Chen, Q. (2013). Efficient Agroinfiltration of Plants for High-level Transient Expression of Recombinant Proteins. Journal of Visualized Experiments: JoVE, (77). https://doi.org/10.3791/50521

Lewis, N. E., Liu, X., Li, Y., Nagarajan, H., Yerganian, G., O’Brien,E., ... Palsson, B. O. (2013). Genomic landscapes of Chinese hamster ovary cell lines as revealed by the Cricetulus griseus draft genome. Nature Biotechnology, 31(8), 759-765.

This article is protected by copyright. All rights reserved. 
Liang, F., Han, M., Romanienko, P. J., \& Jasin, M. (1998). Homology-directed repair is a major double-strand break repair pathway in mammalian cells. Proceedings of the National Academy of Sciences of the United States of America, 95(9), 5172.

Li, F., Vijayasankaran, N., Shen, A. (yijuan), Kiss, R., \& Amanullah, A. (2010). Cell culture processes for monoclonal antibody production. mAbs, 2(5), 466.

Limkul, J., Iizuka, S., Sato, Y., Misaki, R., Ohashi, T., Ohashi, T., \& Fujiyama, K. (2016). The production of human glucocerebrosidase in glyco-engineered Nicotiana benthamiana plants. Plant Biotechnology Journal, 14(8), 1682-1694.

Lindberg, L., Liu, J., Gaunitz, S., Nilsson, A., Johansson, T., Karlsson, N. G., \& Holgersson, J. (2013). Mucin-type fusion proteins with blood group A or B determinants on defined Oglycan core chains produced in glycoengineered Chinese hamster ovary cells and their use as immunoaffinity matrices. Glycobiology, 23(6), 720-735.

Ling, L., Xu, Z. R., Li, W. F., Shuai, J. B., Lu, P., \& Hu, C. X. (2007). Protein secretion pathways in Bacillus subtilis: implication for optimization of heterologous protein secretion. Biotechnology Advances, 25(1), 1-12.

Lis, H., Halina, L. I. S., \& Sharon, N. (1993). Protein glycosylation. Structural and functional aspects. European Journal of Biochemistry / FEBS, 218(1), 1-27.

Liu, J., Jin, C., Cherian, R. M., Karlsson, N. G., \& Holgersson, J. (2015). O -glycan repertoires on a mucin-type reporter protein expressed in $\mathrm{CHO}$ cell pools transiently transfected with O -glycan core enzyme cDNAs. Journal of Biotechnology, 199, 77-89.

This article is protected by copyright. All rights reserved. 
Liu, L. (2015). Antibody glycosylation and its impact on the pharmacokinetics and pharmacodynamics of monoclonal antibodies and Fc-fusion proteins. Journal of Pharmaceutical Sciences, 104(6), 1866-1884.

Liu, X. S., Wu, H., Ji, X., Stelzer, Y., Wu, X., Czauderna, S., ... Jaenisch, R. (2016). Editing DNA Methylation in the Mammalian Genome. Cell, 167(1), 233-247.e17.

Lood, C., Allhorn, M., Lood, R., Gullstrand, B., Olin, A. I., Rönnblom, L., ... Bengtsson, A. A. (2012). IgG glycan hydrolysis by endoglycosidase S diminishes the proinflammatory properties of immune complexes from patients with systemic lupus erythematosus: a possible new treatment? Arthritis and Rheumatism, 64(8), 2698-2706.

Mabashi-Asazuma, H., \& Jarvis, D. L. (2017). CRISPR-Cas9 vectors for genome editing and host engineering in the baculovirus-insect cell system. Proceedings of the National Academy of Sciences, 114(34), 9068-9073.

Macek, B., Gnad, F., Soufi, B., Kumar, C., Olsen, JV., Mijakovic, I., \& Mann, M. (2008). Phosphoproteome analysis of E. coli reveals evolutionary conservation of bacterial Ser/Thr/Tyr phosphorylation. Molecular and Cellular Proteomics, 7(2), 299-307.

Maghodia, A. B., Geisler, C., \& Jarvis, D. L. (2016). Characterization of an Sf-rhabdovirusnegative Spodoptera frugiperda cell line as an alternative host for recombinant protein production in the baculovirus-insect cell system. Protein Expression and Purification, 122, 45-55.

Mali, P., Yang, L., Esvelt, K. M., Aach, J., Guell, M., DiCarlo, J. E., ... Church, G. M. (2013). RNA-Guided Human Genome Engineering via Cas9. Science , 339(6121), 823.

This article is protected by copyright. All rights reserved. 
Malphettes, L., Freyvert, Y., Chang, J., Liu, P.-Q., Chan, E., Miller, J. C., .. Cost, G. J. (2010). Highly efficient deletion of FUT8 in CHO cell lines using zinc-finger nucleases yields cells that produce completely nonfucosylated antibodies. Biotechnology and Bioengineering, 106(5), 774-783.

Mandal, M. K., Ahvari, H., Schillberg, S., \& Schiermeyer, A. (2016). Tackling Unwanted Proteolysis in Plant Production Hosts Used for Molecular Farming. Frontiers in Plant Science, 7, 267.

Marsian, J., \& Lomonossoff, G. P. (2016). Molecular pharming — VLPs made in plants. Current Opinion in Biotechnology, 37, 201-206.

Martínez-Alonso, M., González-Montalbán, N., García-Fruitós, E., \& Villaverde, A. (2009). Learning about protein solubility from bacterial inclusion bodies. Microbial Cell Factories, 8, 4.

Marx, N., Grünwald-Gruber, C., Bydlinski, N., Dhiman, H., Ngoc Nguyen, L., Klanert, G., \& Borth, N. (2018). CRISPR-Based Targeted Epigenetic Editing Enables Gene Expression Modulation of the Silenced Beta-Galactoside Alpha-2,6-Sialyltransferase 1 in CHO Cells. Biotechnology Journal, e1700217.

Mattanovich, D., Branduardi, P., Dato, L., Gasser, B., Sauer, M., \& Porro, D. (2011). Recombinant Protein Production in Yeasts. In Methods in Molecular Biology (pp. 329358).

Mbewana, S., Mortimer, E., Pêra, F. F. P. G., Hitzeroth, I. I., \& Rybicki, E. P. (2015). Production of H5N1 Influenza Virus Matrix Protein 2 Ectodomain Protein Bodies in Tobacco This article is protected by copyright. All rights reserved. 
Plants and in Insect Cells as a Candidate Universal Influenza Vaccine. Frontiers in Bioengineering and Biotechnology, 3, 197.

Meghrous, J., Khramtsov, N., Buckland, B. C., Cox, M. M. J., Palomares, L. A., \& Srivastava, I. K. (2015). Dissolved carbon dioxide determines the productivity of a recombinant hemagglutinin component of an influenza vaccine produced by insect cells. Biotechnology and Bioengineering, 112(11), 2267-2275.

Mercx, S., Smargiasso, N., Chaumont, F., De Pauw, E., Boutry, M., \& Navarre, C. (2017). Inactivation of the $\beta(1,2)$-xylosyltransferase and the $\alpha(1,3)$-fucosyltransferase genes in Nicotiana tabacum BY-2 Cells by a Multiplex CRISPR/Cas9 Strategy Results in Glycoproteins without Plant-Specific Glycans. Frontiers in Plant Science, 8. https://doi.org/10.3389/fpls.2017.00403

Miller, J. C., Tan, S., Qiao, G., Barlow, K. A., Wang, J., Xia, D. F., ... Rebar, E. J. (2011). A TALE nuclease architecture for efficient genome editing. Nature Biotechnology, 29(2), $143-148$.

Miller, S. I., \& Salama, N. R. (2018). The gram-negative bacterial periplasm: Size matters. PLoS Biology, 16(1), e2004935.

Miyaoka, Y., Berman, J. R., Cooper, S. B., Mayerl, S. J., Chan, A. H., Zhang, B., ... Conklin, B. R. (2016). Systematic quantification of HDR and NHEJ reveals effects of locus, nuclease, and cell type on genome-editing. Scientific Reports, 6, 23549.

This article is protected by copyright. All rights reserved. 
Monroe, R. S., \& Huber, B. E. (1995). The major form of the murine asialoglycoprotein receptor: cDNA sequence and expression in liver, testis and epididymis [Gene 148 (1995) 237-244]. Gene, 161(2), 307.

Moore, K. L. (2003). The biology and enzymology of protein tyrosine O-sulfation. The Journal of Biological Chemistry, 278(27), 24243-24246.

Mori, K., Kuni-Kamochi, R., Yamane-Ohnuki, N., Wakitani, M., Yamano, K., Imai, H., ... Satoh, M. (2004). Engineering Chinese hamster ovary cells to maximize effector function of produced antibodies using FUT8 siRNA. Biotechnology and Bioengineering, 88(7), 901-908.

Nagahashi, K., Umemura, K., Kanayama, N., \& Iwaki, T. (2017). Successful synthesis of active human coagulation factor VII by co-expression of mammalian gamma-glutamyl carboxylase and modification of vit.K cycle in Drosophila Schneider S2 cells. Cytotechnology, 69(2), 317.

Nandakumar, S., Ma, H., \& Khan, A. S. (2017). Whole-Genome Sequence of the Spodoptera frugiperda Sf9 Insect Cell Line. Genome Announcements, 5(34). https://doi.org/10.1128/genomea.00829-17.

Nasab, F. P., Aebi, M., Bernhard, G., \& Frey, A. D. (2013). A Combined System for Engineering Glycosylation Efficiency and Glycan Structure in Saccharomyces cerevisiae. Applied and Environmental Microbiology, 79(3), 997.

Naso, M. F., Tam, S. H., Scallon, B. J. \& Raju, T. S. (2010). Engineering host cell lines to reduce terminal sialylation of secreted antibodies. Mabs, 2(5), 519-27.

This article is protected by copyright. All rights reserved. 
Nielsen, J. (2013). Production of biopharmaceutical proteins by yeast. Bioengineered, 4(4), 207211.

Nozaki, T., Imai, R., Tanbo, M., Nagashima, R., Tamura, S., Tani, T., ... Maeshima, K. (2017). Dynamic Organization of Chromatin Domains Revealed by Super-Resolution Live-Cell Imaging. Molecular Cell, 67(2), 282-293.

O’Geen, H., Ren, C., Nicolet, C. M., Perez, A. A., Halmai, J., Le, V. M., ... Segal, D. J. (2017). dCas9-based epigenome editing suggests acquisition of histone methylation is not sufficient for target gene repression. Nucleic Acids Research, 45(17), 9901.

Peter, J., De Chiara, M., Friedrich, A., Yue, J-X., Pflieger, D., Bergström, A., ... Schacherer, J. (2018). Genome evolution across 1,011 Saccharomyces cerevisiae isolates. Nature, 556, 339-344.

Pillay, P., Schlüter, U., van Wyk, S., Kunert, K. J., \& Vorster, B. J. (2014). Proteolysis of recombinant proteins in bioengineered plant cells. Bioengineered, 5(1), 15-20.

Ptacek, J., Devgan, G., Michaud, G., Zhu, H., Zhu, X., Fasolo, J., ... Snyder, M. (2005). Global analysis of protein phosphorylation in yeast. Nature, 438, 679-684.

Qi, L. S., Larson, M. H., Gilbert, L. A., Doudna, J. A., Weissman, J. S., Arkin, A. P., \& Lim, W. A. (2013). Repurposing CRISPR as an RNA-Guided Platform for Sequence-Specific Control of Gene Expression. Cell, 152(5), 1173.

Raab, N., Mathias, S., Alt, K., Handrick, R., Fischer, S., Schmieder, ... Otte, K. (2019). CRISPR/Cas9-mediated knockout of microRNA-744 improves antibody titer of CHO

This article is protected by copyright. All rights reserved. 
production cell lines. Biotechnology Journal, e1800477. https://doi.org/10.1002/biot.201800477.

Rand, M. D., Kalafatis, M., \& Mann, K. G. (1994). Platelet coagulation factor Va: the major secretory platelet phosphoprotein. Blood, 83(8), 2180-2190.

Raven, N., Rasche, S., Kuehn, C., Anderlei, T., Klöckner, W., Schuster, F., ... Schillberg, S. (2015). Scaled-up manufacturing of recombinant antibodies produced by plant cells in a 200-L orbitally-shaken disposable bioreactor. Biotechnology and Bioengineering, 112(2), 308-321.

Raymond, C., Robotham, A., Kelly, J., Lattova, E., Perreault, H., \& Durocher, Y. (2012). Production of Highly Sialylated Monoclonal Antibodies. In Glycosylation.

Reuter, L. J., Bailey, M. J., Joensuu, J. J., \& Ritala, A. (2014). Scale-up of hydrophobin-assisted recombinant protein production in tobacco BY-2 suspension cells. Plant Biotechnology Journal, 12(4), 402-410.

Roldão, A., Vicente, T., Peixoto, C., Carrondo, M. J. T., \& Alves, P. M. (2011). Quality control and analytical methods for baculovirus-based products. Journal of Invertebrate Pathology, 107 Suppl, S94-S105.

Ronda, C., Pedersen, L. E., Hansen, H. G., Kallehauge, T. B., Betenbaugh, M. J., Nielsen, A. T., \& Kildegaard, H. F. (2014). Accelerating genome editing in CHO cells using CRISPR Cas9 and CRISPy, a web-based target finding tool. Biotechnology and Bioengineering, 111(8), 1604-1616.

This article is protected by copyright. All rights reserved. 
Rupp, O., MacDonald, M. L., Li, S., Dhiman, H., Polson, S., Griep, S., ... Lee, K. H. (2018). A reference genome of the Chinese hamster based on a hybrid assembly strategy. Biotechnology and Bioengineering, 115(8), 2087-2100.

Sahdev, S., Khattar, S. K., \& Saini, K. S. (2008). Production of active eukaryotic proteins through bacterial expression systems: a review of the existing biotechnology strategies. Molecular and Cellular Biochemistry, 307(1-2), 249-264.

Saitua, F., Torres, P., Pérez-Correa, J. R., \& Agosin, E. (2017). Dynamic genome-scale metabolic modeling of the yeast Pichia pastoris. BMC Systems Biology, 11(1), 27.

Sakuma, T., Takenaga, M., Kawabe, Y., Nakamura, T., Kamihira, M., \& Yamamoto, T. (2015). Homologous Recombination-Independent Large Gene Cassette Knock-in in CHO Cells Using TALEN and MMEJ-Directed Donor Plasmids. International Journal of Molecular Sciences, 16(10), 23849-23866.

Sandig, G., von Horsten, H. H., Radke, L., Blanchard, V., Frohme, M., Giese, C., ... Hinderlich, S. (2017). Engineering of CHO Cells for the Production of Recombinant Glycoprotein Vaccines with Xylosylated N-glycans. Bioengineering (Basel, Switzerland), 4(2). https://doi.org/10.3390/bioengineering4020038

Santiago, Y., Chan, E., Liu, P.-Q., Orlando, S., Zhang, L., Urnov, F. D., ... Collingwood, T. N. (2008). Targeted gene knockout in mammalian cells by using engineered zinc-finger nucleases. Proceedings of the National Academy of Sciences of the United States of America, 105(15), 5809-5814.

This article is protected by copyright. All rights reserved. 
Sareneva, T., Cantell, K., Pyhälä, L., Pirhonen, J., \& Julkunen, I. (1993). Effect of Carbohydrates on the Pharmacokinetics of Human Interferon- $\gamma$. Journal of Interferon Research, 13(4), 267-269.

Schirmer, M., Smeekens, S. P., Vlamakis, H., Jaeger, M., Oosting, M., Franzosa, E. A., ... Xavier, R. J. (2016). Linking the Human Gut Microbiome to Inflammatory Cytokine Production Capacity. Cell, 167(4), 1125-1136.e8.

Schmidt, F. R. (2004). Recombinant expression systems in the pharmaceutical industry. Applied Microbiology and Biotechnology, 65(4), 363-372.

Schmieder, V., Bydlinski, N., Strasser, R., Baumann, M., Kildegaard, H. F., Jadhav, V., \& Borth, N. (2017). Enhanced Genome Editing Tools For Multi-Gene Deletion Knock-Out Approaches Using Paired CRISPR sgRNAs in CHO Cells. Biotechnology Journal, 13(3), 1700211.

Shaaltiel, Y., Bartfeld, D., Hashmueli, S., Baum, G., Brill-Almon, E., Galili, G., ... Aviezer, D. (2007). Production of glucocerebrosidase with terminal mannose glycans for enzyme replacement therapy of Gaucher’s disease using a plant cell system. Plant Biotechnology Journal, 5(5), 579-590.

Shawn Liu, X., Wu, H., Ji, X., Stelzer, Y., Wu, X., Czauderna, S., ... Jaenisch, R. (2016). Editing DNA methylation in the mammalian genome. Cell, 167(1), 233.

Shcherbakova, O. G., Lanzov, V. A., Ogawa, H., \& Filatov, M. V. (2000). Overexpression of bacterial RecA protein stimulates homologous recombination in somatic mammalian cells. Mutation Research, 459(1), 65-71.

This article is protected by copyright. All rights reserved. 
Shimamoto, G., Gegg, C., Boone, T., \& Quéva, C. (2012). Peptibodies: A flexible alternative format to antibodies. $m A b s, 4(5), 586-591$.

Stavenhagen, K., Kayili, H. M., Holst, S., Koeleman, C. A. M., Engel, R., Wouters, D., ... Wuhrer, M. (2018). N- and -glycosylation Analysis of Human C1-inhibitor Reveals Extensive Mucin-type -Glycosylation. Molecular \& Cellular Proteomics: MCP, 17(6), $1225-1238$.

Sternberg, S. H., Redding, S., Jinek, M., Greene, E. C., \& Doudna, J. A. (2014). DNA interrogation by the CRISPR RNA-guided endonuclease Cas9. Nature, 507(7490), 6267.

Stolfa, G., Smonskey, M. T., Boniface, R., Hachmann, A.-B., Gulde, P., Joshi, A. D., ... Campbell, A. (2018). CHO-Omics Review: The Impact of Current and Emerging Technologies on Chinese Hamster Ovary Based Bioproduction. Biotechnology Journal, 13(3), e1700227.

Stone, M. J., Chuang, S., Hou, X., Shoham, M., Zhu, J. Z. (2009). Tyrosine sulfation: an increasingly recognized post-translational modification of secreted proteins. New Biotechnology, 25(5), 299-317.

Strasser R, Stadlmann, J., Schähs, M., Stiegler, G., Quendler, H., Mach, L., \& Steinkellner, H. (2008). Generation of glyco-engineered Nicotiana benthamiana for the production of monoclonal antibodies with a homogeneous human-like N-glycan structure. Plant Biotechnology Journal, 6(4), 392-402.

This article is protected by copyright. All rights reserved. 
Strasser, R., Altmann, F., \& Steinkellner, H. (2014). Controlled glycosylation of plant-produced recombinant proteins. Current Opinion in Biotechnology, 30, 95-100.

Sturmberger, L., Chappell, T., Geier, M., Krainer, F., Day, K. J., Vide, U., ... Glieder, A. (2016). Refined Pichia pastoris reference genome sequence. Journal of Biotechnology, 235, $121-131$.

Su, W. W., Lee, K-T. (2007). Plant Cell and Hairy Root Cultures - Process Characteristics, Products, and Applications. Bioprocessing for Value-Added Products from Renewable Resources, 263-292. https://doi.org/10.1016/B978-044452114-9/50011-6.

Subedi, G. P., Johnson, R. W., Moniz, H. A., Moremen, K. W., \& Barb, A. (2015). High Yield Expression of Recombinant Human Proteins with the Transient Transfection of HEK293 Cells in Suspension. Journal of Visualized Experiments: JoVE, (106). https://doi.org/10.3791/53568

Suflita, M., Fu, L., He, W., Koffas, M., \& Linhardt, R. J. (2015). Heparin and related polysaccharides: synthesis using recombinant enzymes and metabolic engineering. Applied Microbiology and Biotechnology, 99(18), 7465-7479.

Swiech, K., Picanço-Castro, V., \& Covas, D. T. (2017). Production of recombinant coagulation factors: Are humans the best host cells? Bioengineered, 8(5), 462.

Szymanski, C. M., Yao, R., Ewing, C. P., Trust, T. J., \& Guerry, P. (1999). Evidence for a system of general protein glycosylation in Campylobacter jejuni. Molecular Microbiology, 32(5), 1022-1030.

This article is protected by copyright. All rights reserved. 
Tang, H., Wang, S., Wang, J., Song, M., Xu, M., Zhang, M., ... Bao, X. (2016). Nhypermannose glycosylation disruption enhances recombinant protein production by regulating secretory pathway and cell wall integrity in Saccharomyces cerevisiae. Scientific Reports, 6, 25654.

Tanner, W., \& Lehle, L. (1987). Protein glycosylation in yeast. Biochimica et Biophysica Acta, 906(1), 81-99.

Taschwer, M., Hackl, M., Hernández Bort, J. A., Leitner, C., Kumar, N., Puc, U., ... Borth, N. (2012). Growth, productivity and protein glycosylation in a CHO EpoFc producer cell line adapted to glutamine-free growth. Journal of Biotechnology, 157(2), 295-303.

Taticek, R. A., Choi, C., Phan, S-E., Palomares, L. A., Shuler, M. L. (2008). Comparison of Growth and Recombinant Protein Expression in Two Different Insect Cell Lines in Attached and Suspension Culture. Biotechnology Progress, 17(4), 676-684.

Tejwani, V., Andersen, M. R., Nam, J. H., \& Sharfstein, S. T. (2018). Glycoengineering in CHO Cells: Advances in Systems Biology. Biotechnology Journal, 13(3), 1700234.

Tekoah, Y., Tzaban, S., Kizhner, T., Hainrichson, M., Gantman, A., Golembo, M., ... Shaaltiel, Y. (2013). Glycosylation and functionality of recombinant $\beta$-glucocerebrosidase from various production systems. Bioscience Reports, 33(5). https://doi.org/10.1042/BSR20130081

Thibault, P., Logan, S. M., Kelly, J. F., Brisson, J. R., Ewing, C. P., Trust, T. J., \& Guerry, P. (2001). Identification of the carbohydrate moieties and glycosylation motifs in

This article is protected by copyright. All rights reserved. 
Campylobacter jejuni flagellin. The Journal of Biological Chemistry, 276(37), 3486234870.

Ul Ain, Q., Chung, J. Y., \& Kim, Y.-H. (2015). Current and future delivery systems for engineered nucleases: ZFN, TALEN and RGEN. Journal of Controlled Release: Official Journal of the Controlled Release Society, 205, 120-127.

Umaña, P., Jean-Mairet, J., Moudry, R., Amstutz, H., \& Bailey, J. E. (1999). Engineered glycoforms of an antineuroblastoma IgG1 with optimized antibody-dependent cellular cytotoxic activity. Nature Biotechnology, 17(2), 176-180.

Valderrama-Rincon, J. D., Fisher, A. C., Merritt, J. H., Fan, Y.-Y., Reading, C. A., Chhiba, K., ... DeLisa, M. P. (2012). An engineered eukaryotic protein glycosylation pathway in Escherichia coli. Nature Chemical Biology, 8(5), 434-436.

van Veen, H. A., Koiter, J., Vogelezang, C. J. M., van Wessel, N., van Dam, T., Velterop, I., ... Mannesse, M. L. M. (2012). Characterization of recombinant human C1 inhibitor secreted in milk of transgenic rabbits. Journal of Biotechnology, 162(2-3), 319-326.

Vatandoost, J., \& Pakdaman, S. F. (2016). The Effects of Influencing Factors on $\gamma$-carboxylation and Expression of Recombinant Vitamin K Dependent Coagulation Factors. Journal of Biomedicine \& Biotechnology, 1(2). https://doi.org/10.17795/jmb-6077

Vcelar, S., Jadhav, V., Melcher, M., Auer, N., Hrdina, A., Sagmeister, R., ... Borth, N. (2018). Karyotype variation of $\mathrm{CHO}$ host cell lines over time in culture characterized by chromosome counting and chromosome painting. Biotechnology and Bioengineering, 115(1), 165-173.

This article is protected by copyright. All rights reserved. 
Vcelar, S., Melcher, M., Auer, N., Hrdina, A., Puklowski, A., Leisch, F., ... Borth, N. (2018). Changes in Chromosome Counts and Patterns in CHO Cell Lines upon Generation of Recombinant Cell Lines and Subcloning. Biotechnology Journal, 13(3), 1700495.

Venter, J. C., Adams, M. D., Myers, E. W., Li, P. W., Mural, R. J., Sutton, G. G., ...Zhu, X. (2001). The sequence of the human genome. Science, 291(5507), 1304-1351.

Vieira Gomes, A. M., Souza Carmo, T., Silva Carvalho, L., Mendonça Bahia, F., Parachin, N. S. (2018). Comparison of Yeasts as Hosts for Recombinant Protein Production. Microorganisms, 6(2), 38.

Wacker, M. (2002). N-Linked Glycosylation in Campylobacter jejuni and Its Functional Transfer into E. coli. Science, 298(5599), 1790-1793.

Wajih, N., Hutson, S. M., Owen, J., \& Wallin, R. (2005). Increased production of functional recombinant human clotting factor IX by baby hamster kidney cells engineered to overexpress VKORC1, the vitamin K 2,3-epoxide-reducing enzyme of the vitamin $\mathrm{K}$ cycle. The Journal of Biological Chemistry, 280(36), 31603-31607.

Wajih, N., Hutson, S. M., \& Wallin, R. (2006). siRNA silencing of calumenin enhances functional factor IX production. Blood, 108(12), 3757.

Walsh, G. (2009). Post-translational Modification of Protein Biopharmaceuticals. John Wiley \& Sons.

Walsh, G. (2010). Post-translational modifications of protein biopharmaceuticals. Drug Discovery Today, 15(17-18), 773-780.

This article is protected by copyright. All rights reserved. 
Walsh, G. (2014). Biopharmaceutical benchmarks 2014. Nature Biotechnology, 32(10), 9921000.

Wang, H., Song, H.-L., Wang, Q., \& Qiu, B.-S. (2013). Expression of glycoproteins bearing complex human-like glycans with galactose terminal in Hansenula polymorpha. World Journal of Microbiology \& Biotechnology, 29(3), 447-458.

Weis, B. L., Guth, N., Fischer, S., Wissing, S., Fradin, S., Holzmann, K.-H., ... Otte, K. (2018). Stable miRNA overexpression in human CAP cells: Engineering alternative production systems for advanced manufacturing of biologics using miR-136 and miR-3074. Biotechnology and Bioengineering, 115(8), 2027-2038.

Werner, R. G., Kopp, K., \& Schlueter, M. (2007). Glycosylation of therapeutic proteins in different production systems. Acta Paediatrica, 96, 17-22.

Wu C, E., Shopsowitz, K. E., \& Hammond, P. T. (2016). Engineering Periodic shRNA for Enhanced Silencing Efficacy. Molecular Therapy, 24(6), 1070-1077.

Wurm, F. M. (2004). Production of recombinant protein therapeutics in cultivated mammalian cells. Nature Biotechnology, 22(11), 1393-1398.

Xiong, K, Marquart, K. F., Karottki, K. J. C., Li, S., Shamie I., Lee, J., ... Kildegaard, H. F. (2019). Reduced Apoptosis in Chinese Hamster Ovary Cells via Optimized CRISPR Interference. Biotechnology and Bioengineering, https://doi.org/10.1002/bit.26969.

This article is protected by copyright. All rights reserved. 
Xu, X., Nagarajan, H., Lewis, N. E., Pan, S., Cai, Z., Liu, X., ... Wang, J. (2011). The genomic sequence of the Chinese hamster ovary (CHO)-K1 cell line. Nature Biotechnology, 29(8), 735-741.

Xu, X., Tao, Y., Gao, X., Zhang, L., Li, X., Zou, W., ... Hu, R. (2016). A CRISPR-based approach for targeted DNA demethylation. Cell Discovery, 2, 16009.

Yalak, G., \& Vogel, V. (2012). Extracellular Phosphorylation and Phosphorylated Proteins: Not Just Curiosities But Physiologically Important. Science Signaling, 5(255), re7-re7.

Yamane-Ohnuki, N., Kinoshita, S., Inoue-Urakubo, M., Kusunoki, M., Iida, S., Nakano, R., ... Satoh, M. (2004). Establishment of FUT8 knockout Chinese hamster ovary cells: an ideal host cell line for producing completely defucosylated antibodies with enhanced antibody-dependent cellular cytotoxicity. Biotechnology and Bioengineering, 87(5), $614-622$.

Yang, Z., Bennett, E. P., Jørgensen, B., Drew, D. P., Arigi, E., Mandel, U., ... Petersen, B. L. (2012). Toward stable genetic engineering of human O-glycosylation in plants. Plant Physiology, 160(1), 450-463.

Yang, Z., Halim, A., Narimatsu, Y., Joshi, H. J., Steentoft, C., Schjoldager, K. T.-B. G., ... Clausen, H. (2014). The GalNAc-type O-Glycoproteome of CHO Cells Characterized by the SimpleCell Strategy. Molecular \& Cellular Proteomics: MCP, 13(12), 32243235.

This article is protected by copyright. All rights reserved. 
Yang, Z., Wang, S., Halim, A., Schulz, M. A., Frodin, M., Rahman, S. H., ... Clausen, H. (2015). Engineered CHO cells for production of diverse, homogeneous glycoproteins. Nature Biotechnology, 33(8), 842-844.

Yao, T., \& Asayama, Y. (2017). Animal-cell culture media: History, characteristics, and current issues. Reproductive Medicine and Biology, 16(2), 99-117.

Yates, L. E., Mills, D. C., \& DeLisa, M. P. (2018). Bacterial Glycoengineering as a Biosynthetic Route to Customized Glycomolecules. In Advances in Biochemical Engineering/Biotechnology.

Yuan, H., Cheung, C. Y. M., Hilbers, P. A. J., \& van Riel, N. A. W. (2016). Flux Balance Analysis of Plant Metabolism: The Effect of Biomass Composition and Model Structure on Model Predictions. Frontiers in Plant Science, 7. https://doi.org/10.3389/fpls.2016.00537

Yue, B.-G., Ajuh, P., Akusjärvi, G., Lamond, A. I., \& Kreivi, J.-P. (2000). Functional coexpression of serine protein kinase SRPK1 and its substrate ASF/SF2 in Escherichia coli. Nucleic Acids Research, 28(5), e14.

Zhang, J., Suflita, M., Li, G., Zhong, W., Li, L., Dordick, J. S., ... Zhang, F. (2015). High cell density cultivation of recombinant Escherichia coli strains expressing 2-Osulfotransferase and C5-epimerase for the production of bioengineered heparin. Applied Biochemistry and Biotechnology, 175(6), 2986-2995.

Zhang, L., Luo, S., \& Zhang, B. (2016). The use of lectin microarray for assessing glycosylation of therapeutic proteins. mAbs, 8(3), 524-535.

This article is protected by copyright. All rights reserved. 
Zhang, M., Koskie, K., Ross, J. S., Kayser, K. J., \& Caple, M. V. (2010). Enhancing glycoprotein sialylation by targeted gene silencing in mammalian cells. Biotechnology and Bioengineering, 105(6), 1094-1105.

Zhao, J., Saunders, J., Schussler, S. D., Rios, S., Insaidoo, F. K., Fridman, A. L., ... Liu, Y.-H. (2017). Characterization of a novel modification of a CHO-produced mAb: Evidence for the presence of tyrosine sulfation. $m A b s, 9(6), 985$.

Zhao, W.-N., \& McAlister-Henn, L. (1996). Expression and Gene Disruption Analysis of the Isocitrate Dehydrogenase Family in Yeast $\dagger$. Biochemistry, 35(24), 7873-7878.

Zheng, Q., Cai, X., Tan, M. H., Schaffert, S., Arnold, C. P., Gong, X., ... Huang, S. (2014). Precise gene deletion and replacement using the CRISPR/Cas9 system in human cells. BioTechniques, 57(3), 115-124.

Zhong, X., Desilva, T., Lin, L., Bodine, P., Bhat, R. A., Presman, E., Pocas, J., Stahl, M., Kriz, R. (2007). Regulation of secreted frizzled-related protein-1 by heparin. The Journal of Biological Chemistry, 282, 20523-20533.

Zimran, A., Brill-Almon, E., Chertkoff, R., Petakov, M., Blanco-Favela, F., Muñoz, E. T., ... Aviezer, D. (2011). Pivotal trial with plant cell-expressed recombinant glucocerebrosidase, taliglucerase alfa, a novel enzyme replacement therapy for Gaucher disease. Blood, 118(22), 5767-5773

This article is protected by copyright. All rights reserved. 


\subsection{Tables}

Table 1. Summary of available expression systems and evaluation of their corresponding

\section{characteristics.}

\begin{tabular}{|c|c|c|c|c|c|c|}
\hline & \multicolumn{6}{|c|}{ Expression platforms } \\
\hline & $\begin{array}{c}\text { Mammalian, } \\
\text { human }\end{array}$ & $\begin{array}{l}\text { Mammalian, non- } \\
\text { human, CHO }\end{array}$ & Bacteria & Yeast & Plant & Insect \\
\hline $\begin{array}{l}\text { Biopharmaceutical } \\
\text { complexity }\end{array}$ & +++ & +++ & + & ++ & ++ & ++ \\
\hline Genome size & +++ & +++ & + & + & $++/+++$ & ++ \\
\hline Genome sequence availability & +++ & ++ & +++ & +++ & + & + \\
\hline Molecular tool box & ++ & ++ & +++ & +++ & + & + \\
\hline PTMs & +++ & +++ & + & ++ & ++ & ++ \\
\hline Folding \& secretion & +++ & +++ & + & ++ & ++ & ++ \\
\hline Growth & + & ++ & +++ & +++ & ++ & ++ \\
\hline Productivity & + & ++ & ++ & +++ & + & ++ \\
\hline Bioprocessing & ++ & ++ & +++ & +++ & ++ & ++ \\
\hline Scalability & ++ & +++ & +++ & +++ & ++ & ++ \\
\hline Biosafety & ++ & +++ & + & ++ & ++ & ++ \\
\hline Approvals & ++ & +++ & ++ & ++ & + & + \\
\hline
\end{tabular}

This article is protected by copyright. All rights reserved. 
Table 2. Genetic engineering approaches to improve product quality attributes in different expression platforms.

\begin{tabular}{|c|c|c|c|c|}
\hline Product & Organism & Engineering tool (target) & Described effect & Reference \\
\hline \multicolumn{5}{|c|}{$\mathrm{N}$-glycosylation } \\
\hline НСР & $\mathrm{CHO}(\mathrm{UH})$ & asRNA KD (CMAH) & Neu5GC $\downarrow$ & $\begin{array}{l}\text { (Chenu et al., } \\
\text { 2003) }\end{array}$ \\
\hline EPO & $\begin{array}{l}\text { CHO } \\
\text { (DuxB11) }\end{array}$ & CRISPRa (ST6GAL1) & a-2,6-sialylation $\uparrow$ & $\begin{array}{l}\text { (Marx et al., } \\
\text { 2018) }\end{array}$ \\
\hline $\mathrm{mAb}$ & CHO, BHK & OE (ST6GAL1) & a-2,6-sialylation $\uparrow$ & $\begin{array}{l}\text { (Raymond et } \\
\text { al., 2012) }\end{array}$ \\
\hline $\mathrm{mAb}$ & CHO (DG44) & siRNA KD (FUT8) & Fucosylation $\downarrow$ & $\begin{array}{l}\text { (Mori et al., } \\
\text { 2004) }\end{array}$ \\
\hline $\mathrm{mAb}$ & $\mathrm{CHO}(\mathrm{K} 1)$ & ZFN KO (FUT8) & Fucosylation $\downarrow$ & $\begin{array}{l}\text { (Malphettes } \\
\text { et al., 2010) }\end{array}$ \\
\hline НCP & $\mathrm{CHO}(\mathrm{K} 1)$ & CRISPR KO (FUT8) & Fucosylation $\downarrow$ & $\begin{array}{l}\text { (Ronda et al., } \\
\text { 2014) }\end{array}$ \\
\hline IFN-y & $\mathrm{CHO}$ (DG44) & siRNA/shRNA KD (NEU1, NEU3) & Sialylation $\uparrow$ & $\begin{array}{l}\text { (Zhang et al., } \\
\text { 2010) }\end{array}$ \\
\hline EPO, mAb & $\mathrm{CHO}(\mathrm{S})$ & $\begin{array}{l}\text { CRISPR KO } \\
\text { (B4GALT1,B4GALT2,B4GALT3,B4GALT4) }\end{array}$ & Galactosylation $\downarrow$ & $\begin{array}{l}\text { (Amann et } \\
\text { al., 2018) }\end{array}$ \\
\hline EPO, mAb & $\mathrm{CHO}(\mathrm{K} 1)$ & ZFN KO (19 genes); OE (ST6GAL1) & $\begin{array}{l}\text { Fucosylation } \downarrow \\
\text { a-2,6-sialylation } \uparrow\end{array}$ & $\begin{array}{l}\text { (Yang et al., } \\
\text { 2015) }\end{array}$ \\
\hline
\end{tabular}

This article is protected by copyright. All rights reserved. 


\begin{tabular}{|c|c|c|c|c|}
\hline & & & $\begin{array}{l}\text { Galactosylation } \downarrow \\
\text { Microheterogeneity } \downarrow\end{array}$ & \\
\hline $\begin{array}{l}\text { Vaccine (RSV- } \\
\mathrm{F}^{1} \text { ) }\end{array}$ & CHO (DG44) & OE (XYLT) & Xylosylation $\uparrow$ & $\begin{array}{l}\text { (Sandig et al., } \\
\text { 2017) }\end{array}$ \\
\hline НCP & E. coli & OE (pglB $/$ STT3D) & Complex type $\uparrow$ & $\begin{array}{l}\text { (Wacker, } \\
\text { 2002) }\end{array}$ \\
\hline $\mathrm{scFv}$ & E. coli & OE (ALG1,ALG2,ALG13,ALG14) & Complex type $\uparrow$ & $\begin{array}{l}\text { (Valderrama- } \\
\text { Rincon et al., } \\
\text { 2012) }\end{array}$ \\
\hline НСР & P. pastoris & $\begin{array}{l}\text { KO (OCH1); } \\
\text { OE (GNTI,GNTII,B4GALT,MANI,MANII) }\end{array}$ & High-mannose $\downarrow$ & $\begin{array}{l}\text { (Jacobs et al., } \\
\text { 2009) }\end{array}$ \\
\hline $\mathrm{mAb}$ & S. cerevisiae & $\begin{array}{l}\text { KO (ALG3,ALG11,MNN); } \\
\text { OE (GNTI,GNTII,STT3D,FLC2') }\end{array}$ & High-mannose $\downarrow$ & $\begin{array}{l}\text { (Nasab et al., } \\
\text { 2013) }\end{array}$ \\
\hline $\begin{array}{l}\text { Glucose } \\
\text { oxidase }\end{array}$ & $\begin{array}{l}\text { H. } \\
\text { polymorpha }\end{array}$ & $\begin{array}{l}\text { KO (ALG3,ALG11,OCH1); OE } \\
\text { (GNTI,GNTII,B4GALT) }\end{array}$ & High-mannose $\downarrow$ & $\begin{array}{l}\text { (Wang et al., } \\
\text { 2013) }\end{array}$ \\
\hline Lipase 2 & Y. lipolytica ${ }^{3}$ & KO (ALG3); OE (ALG6) & High-mannose $\downarrow$ & $\begin{array}{l}\text { (De Pourcq, } \\
\text { Tiels, et al., } \\
\text { 2012) }\end{array}$ \\
\hline GC & Y. lipolytica & KO (OCH1,MNN5); OE (MAN) & High-mannose $\downarrow$ & $\begin{array}{l}\text { (De Pourcq, } \\
\text { Vervecken, et } \\
\text { al., 2012) }\end{array}$ \\
\hline rhEPO & P. pastoris & OE of 14 genes, KO of 4 genes & $\begin{array}{l}>90 \% \text { terminal } \\
\text { sialylation; } \\
\text { Complex type } \uparrow\end{array}$ & $\begin{array}{l}\text { (Hamilton et } \\
\text { al., 2006) }\end{array}$ \\
\hline
\end{tabular}

This article is protected by copyright. All rights reserved. 


\begin{tabular}{|c|c|c|c|c|}
\hline $\begin{array}{l}\text { mAb, rhGM- } \\
\text { CSF }\end{array}$ & P. pastoris & OE (STT3D) & Macroheterogeneity $\downarrow$ & $\begin{array}{l}\text { (Choi et al., } \\
\text { 2012) }\end{array}$ \\
\hline GC & $\begin{array}{l}N . \\
\text { benthamiana }\end{array}$ & RNAi (GNTI) & $\begin{array}{l}\text { Immunogenic plant } \\
\text { sugar residues } \downarrow\end{array}$ & $\begin{array}{l}\text { (Limkul et } \\
\text { al., 2016) }\end{array}$ \\
\hline $\mathrm{mAb}$ & L. minor ${ }^{7}$ & siRNA KD (XYLT/FUT) & $\begin{array}{l}\text { Immunogenic plant } \\
\text { sugar residues } \downarrow\end{array}$ & $\begin{array}{l}\text { (Cox et al., } \\
\text { 2006) }\end{array}$ \\
\hline $\mathrm{mAb}$ & N. tabacum & CRISPR/Cas9 KO (XYLT/FUT) & $\begin{array}{l}\text { Immunogenic plant } \\
\text { sugar residues } \downarrow\end{array}$ & $\begin{array}{l}\text { (Mercx et al., } \\
\text { 2017) }\end{array}$ \\
\hline $\mathrm{mAb}$ & $\begin{array}{l}N . \\
\text { benthamiana }\end{array}$ & RNAi (XYLT/FUT) & $\begin{array}{l}\text { Immunogenic plant } \\
\text { sugar residues } \downarrow\end{array}$ & $\begin{array}{l}\text { (Strasser et } \\
\text { al., 2008) }\end{array}$ \\
\hline $\mathrm{mAb}$ & B. mori $^{8}$ & OE (MGAT2,B4GALT) & Complex type $\uparrow$ & $\begin{array}{l}\text { (Kato et al., } \\
\text { 2017) }\end{array}$ \\
\hline $\begin{array}{l}\text { GST-SfManI, } \\
\beta \text {-Trace }{ }^{9}\end{array}$ & Sf9 & OE (MGAT2,B4GALT,ST6GAL1) & Complex type $\uparrow$ & $\begin{array}{l}\text { (Hollister et } \\
\text { al., 2002) }\end{array}$ \\
\hline ЕРО & Sf9 & CRISPR/Cas9 KO (FDL) & paucimannose $\downarrow$ & $\begin{array}{l}\text { (Mabashi- } \\
\text { Asazuma \& } \\
\text { Jarvis, 2017) }\end{array}$ \\
\hline \multicolumn{5}{|c|}{ O-glycosylation } \\
\hline EPO & CHO (K1) & ZFN KO (COSMC, POMGNT1) & O-glycan heterogeneity $\downarrow$ & $\begin{array}{l}\text { (Yang et al., } \\
\text { 2014) }\end{array}$ \\
\hline $\mathrm{YFP}^{10}, \mathrm{IFN} \alpha 2 \mathrm{~B}$ & $\begin{array}{l}\text { N. benthamiana, } \\
\text { A. thaliana }{ }^{11}\end{array}$ & OE $\left(\right.$ GALNT2 $^{12}$, GALNT4, $\left.\mathrm{WBPP}^{13}\right)$ & O-glycosylation $\uparrow$ & $\begin{array}{l}\text { (Yang et al., } \\
\text { 2012) }\end{array}$ \\
\hline EPO-FC & N. benthamiana & OE (GALNT2, ST3GAL,ST6GAL, B3GALT ${ }^{14}$ ) & $\begin{array}{l}\text { di-sialylated core } 1 \text { O- } \\
\text { glycans } \uparrow\end{array}$ & $\begin{array}{l}\text { (Castilho et } \\
\text { al., 2012) }\end{array}$ \\
\hline
\end{tabular}

This article is protected by copyright. All rights reserved. 


\begin{tabular}{|c|c|c|c|c|}
\hline IgA1 & N. benthamiana & KO (XYLT,FUT), OE (GALNT2, C1GALT1) & Core 1 O-glycan $\uparrow$ & $\begin{array}{l}\text { (Dicker et al., } \\
\text { 2016) }\end{array}$ \\
\hline podplanin & S. cerevisiae & OE $\left(\right.$ GALE $^{15}$, SLC35A2 ${ }^{16}$, GALNT1, C1GALT1) & Core 1 O-glycan $\uparrow$ & $\begin{array}{l}\text { (Amano et } \\
\text { al., 2008) }\end{array}$ \\
\hline TNFR $2^{17}$-FC & P. pastoris & OE (MAN1B1, POMGNT1, ST6GAL1, B4GALT) & Sialylation $\uparrow$ & $\begin{array}{l}\text { (Hamilton et } \\
\text { al., 2013) }\end{array}$ \\
\hline $\mathrm{PSGL}^{18} / \mathrm{mIgG} 2 \mathrm{~b}$ & CHO (K1) & OE (B3GNT $\left.{ }^{19} 3, \mathrm{C} \mathrm{GNT}^{20} 1, \mathrm{C} \mathrm{GNT}^{21} 6\right)$ & Elongated O-glycans $\uparrow$ & $\begin{array}{l}\text { (Liu et al., } \\
\text { 2015) }\end{array}$ \\
\hline PSGL1/mIgG2b & CHO (K1) & $\begin{array}{l}\text { OE (C2GNT1, C3GNT5, C3GNT6, FUT1, FUT2, } \\
\text { GALT, GALNT) }\end{array}$ & matured O-glycans $\uparrow$ & $\begin{array}{l}\text { (Lindberg et } \\
\text { al., 2013) }\end{array}$ \\
\hline \multicolumn{5}{|c|}{$\gamma$-Carboxylation } \\
\hline rhFIX & BHK & OE (VKORC1) & carboxylation $\uparrow$ & $\begin{array}{l}\text { (Wajih et al., } \\
\text { 2005) }\end{array}$ \\
\hline rhFIX & BHK21 & siRNA (calumenin) & carboxylation $\uparrow$ & $\begin{array}{l}\text { (Wajih et al., } \\
\text { 2006) }\end{array}$ \\
\hline rhFVII & S2 & OE (GGCX,VKORC1 and/or PDIA2) & carboxylation $\uparrow$ & $\begin{array}{l}\text { (Nagahashi et } \\
\text { al., 2017) }\end{array}$ \\
\hline \multicolumn{5}{|c|}{ Phosphorylation } \\
\hline ASF/SF2 & E. coli & OE (SRPK1) & Phosphorylation $\uparrow$ & $\begin{array}{l}\text { (Yue et al., } \\
2000 \text { ) }\end{array}$ \\
\hline & & Sulfation & & \\
\hline
\end{tabular}

This article is protected by copyright. All rights reserved. 


\begin{tabular}{|l|l|l|l|l|}
\hline HS & CHO-S & OE (Golgi-targeted HS3ST1) & Tyrosine sulfation $\uparrow$ & $\begin{array}{l}\text { (Datta et al., } \\
\text { 2013) }\end{array}$ \\
\hline HS pathway enzym & E.coli & OE (2-OST, C5-epi) & $\begin{array}{l}\text { Recombinant expression of } \\
\text { enzymes for downstream } \\
\text { application }\end{array}$ & $\begin{array}{l}\text { (Zhang et al., } \\
\text { 2015) }\end{array}$ \\
\hline Chondroitin & E.coli & OE (kfoA,kfoC,kfoF) & Tyrosine sulfation $\uparrow$ & (He et al., \\
\hline
\end{tabular}

${ }^{1} \mathrm{RSV}-\mathrm{F}$ - respiratory syncytial virus protein $\mathrm{F} ;{ }^{2}$ pglB - Oligosaccharyltransferase pglB; ${ }^{3}$ Y. lipolytica - Yarrowia lipolytica; ${ }^{4} \mathrm{H}$. Polymorpha Hansenula polymorpha; ${ }^{5}$ MNN - a-1,3-Mannosyltransferase; ${ }^{6}$ FLC2 - Flavin Carrier Protein 2; ${ }^{7}$ L. minor - Lemna minor; ${ }^{8}$ B.mori - Bombyx mori; ${ }^{9}$ GST-SfManI, $\beta$-Trace - GST-tagged soluble domain of the Sf class I Golgi mannosidase; ${ }^{10}$ YPF - yellow fluorescent protein; ${ }^{11} \mathrm{~A}$. thaliana - Arabidopsis thaliana; ${ }^{12}$ GALNT2 - Polypeptide N-Acetylgalactosaminyltransferase $2 ;{ }^{13}$ WBPP - UDP-GlcNAc C4 Epimerase; ${ }^{14}$ B3GALT - $\beta-1,3-$-Galactosyltransferase; ${ }^{15}$ GALE - UDP-Galactose-4-Epimerase; ${ }^{16}$ SLC35A2 - Solute Carrier Family 35 Member A2; ${ }^{17}$ TNFR2 - Tumor Necrosis Factor Receptor 2; ${ }^{18}$ PSGL1 - Selectin P ligand; ${ }^{19}$ B3GNT - $\beta$-1,3-N-acetylglucosaminyltransferase; ${ }^{20}$ C2GNT Glucosaminyl (N-Acetyl) Transferase, Core 2; ${ }^{21}$ C3GNT - Glucosaminyl (N-Acetyl) Transferase, Core 3.

\subsection{Figure}

Figure 1. Overview of N-glycosylation in different wild type expression platforms (adapted from Chung et al. 2017).

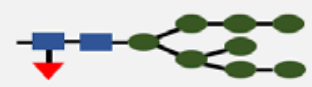

high mannose

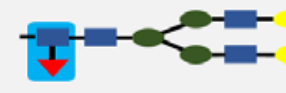

core fucosylation

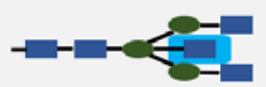

bisecting $\mathbf{N}$-glycan

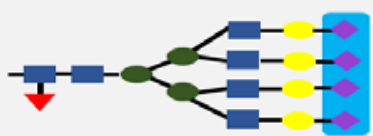

terminal sialylation

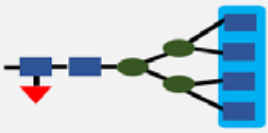

tetra-antennary

MAMMALIAN PLANT

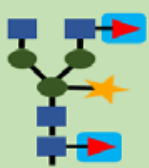

fucosylation

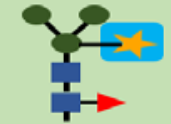

xylosylation

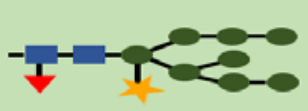

high mannose

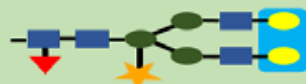

galactosylation

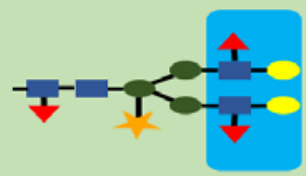

Lewis A-structure

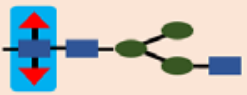

core fucosylation

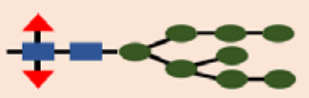

high mannose

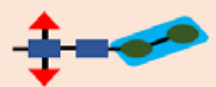

paucimannose

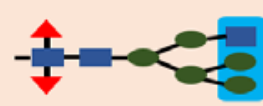

hybrid $\mathbf{N}$-glycan

\section{INSECT}

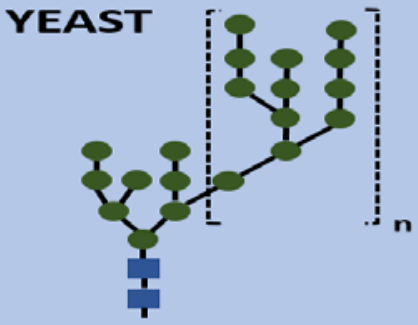

hypermannose

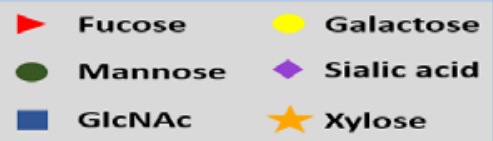

This article is protected by copyright. All rights reserved. 